\title{
Role and Mechanisms of RAGE-Ligand Complexes and RAGE-Inhibitors in Cancer Progression
}

\author{
Ali H. El-Far ${ }^{1}$ (D) , Grazyna Sroga ${ }^{2}$, Soad K. Al Jaouni ${ }^{3}$ and Shaker A. Mousa ${ }^{4, *(D)}$ \\ 1 Department of Biochemistry, Faculty of Veterinary Medicine, Damanhour University, Damanhour, \\ Damanhour 22511, Egypt; ali.elfar@damanhour.edu.eg \\ 2 Rensselaer Polytechnic Institute, NY (RPI), Troy, NY 12180, USA; srogag@rpi.edu \\ 3 Department of Hematology/Pediatric Oncology, King Abdulaziz University, Yousef Abdulatif Jameel \\ Scientific Chair of Prophetic Medicine Application, Faculty of Medicine, King Abdulaziz University, \\ Jeddah 21589, Saudi Arabia; saljaouni@kau.edu.sa \\ 4 The Pharmaceutical Research Institute, Albany College of Pharmacy and Health Sciences, Rensselaer, \\ NY 12144, USA \\ * Correspondence: shaker.mousa@acphs.edu
}

Received: 28 March 2020; Accepted: 8 May 2020; Published: 20 May 2020

\begin{abstract}
Interactions of the receptor for advanced glycation end product (RAGE) and its ligands in the context of their role in diabetes mellitus, inflammation, and carcinogenesis have been extensively investigated. This review focuses on the role of RAGE-ligands and anti-RAGE drugs capable of controlling cancer progression. Different studies have demonstrated interaction of RAGE with a diverse range of acidic (negatively charged) ligands such as advanced glycation end products (AGEs), high-mobility group box1 (HMGB1), and S100s, and their importance to cancer progression. Some RAGE-ligands displayed effects on anti- and pro-apoptotic proteins through upregulation of the phosphatidylinositide 3-kinase (PI3K)/protein kinase B (Akt)/mammalian target of rapamycin (mTOR), mitogen-activated protein kinases (MAPKs), matrix metalloproteinases (MMPs), vascular endothelial growth factor (VEGF), and nuclear factor kappa B (NF- $\mathrm{B}$ ) pathways, while downregulating p53 in cancer progression. In addition, RAGE may undergo ligand-driven multimodal dimerization or oligomerization mediated through self-association of some of its subunits. We conclude our review by proposing possible future lines of study that could result in control of cancer progression through RAGE inhibition.
\end{abstract}

Keywords: RAGE-ligands; AGEs; HMGB1; S100s; RAGE-inhibitors; carcinogenesis

\section{Introduction}

The receptor for advanced glycation end products (RAGE) is involved in various inflammatory and immune responses [1]. Structurally, RAGE is a 45-kDa protein that is highly expressed during embryonic development, especially in the brain, and then its expression decreases in adult tissues [2]. RAGE has been recognized in several diseases with different isoforms including the full-length RAGE, dominant negative RAGE (DN-RAGE), N-truncated RAGE (N-RAGE), and C-truncated secretory/soluble RAGE (sRAGE) $[3,4]$. RAGE is overexpressed on cell surface membrane of activated immune, vascular, and cancer cells [5]. Binding of advanced glycation end products (AGEs), S100 proteins, high-mobility group box1 (HMGB1), amyloid $\beta$-peptide, lipopolysaccharides, $\beta$-sheet fibrils, advanced oxidation protein products, Mac-1, or phosphatidyl serine with RAGE directs the cancer cells toward survival and proliferation [6-8]. Interaction of RAGE with these molecules activates cell signaling pathways such as mitogen-activated protein kinase (MAPK) and nuclear factor kappa B (NF- $\kappa$ B), which induce cellular propagation $[9,10]$. As a result, ligands-induced RAGE signaling increases the malignant progression of glioma, bladder, melanoma, liver, pancreatic, prostate, colorectal, gastric, and lung cancers [11-14]. 
Apoptosis is a programmed cell death, which plays a significant role in tumor invasiveness and metastasis. Any defects in apoptosis play a pivotal role in initiation and progression of carcinogenesis [15]. Hence, cancer cell progression is induced by downregulation of the intrinsic and extrinsic pathways of apoptosis [16,17]. RAGE interferes with apoptosis through a p53-dependent mitochondrial pathway. Furthermore, RAGE controls autophagy through decreased phosphorylation of mammalian target of rapamycin (mTOR), the anti-apoptotic protein, and increased Beclin-1/VPS34 autophagosome formation [18].

In this review, we will discuss the new studies concerning ligands and inhibitors of RAGE and their roles in cancer progression. We recommend some future studies that could help to delineate the mechanism by which RAGE-ligands could induce cancer progression. We also provide a guide for targeted inhibition of RAGE by its ligands, which may serve as novel targets to improve current cancer therapies.

\section{Mechanisms of AGEs-RAGE Axis Cancer Progression}

AGEs are formed through a nonenzymatic process also known as Maillard reaction. This reaction is initiated between the free amino group of a protein and a carbonyl group from a reducing sugar to produce AGEs [19] followed by a series of cascade reactions that include dehydration, oxidation, condensation, and cyclization [20]. The formed AGEs enhance cancer cell migration through the expression of vascular endothelial growth factor (VEGF), NF- $\kappa \mathrm{B}$, and extracellular signal-regulated kinase (ERK) pathways [13,21]. AGEs-RAGE axis has induced cancer cell progression in colon, breast, oral, prostate, and neuroblastoma cell lines (Table 1), and AGEs- RAGE axis can enhance cancer progression through regulation of the pathways and molecules described below and illustrated in Figure 1 [21-27].

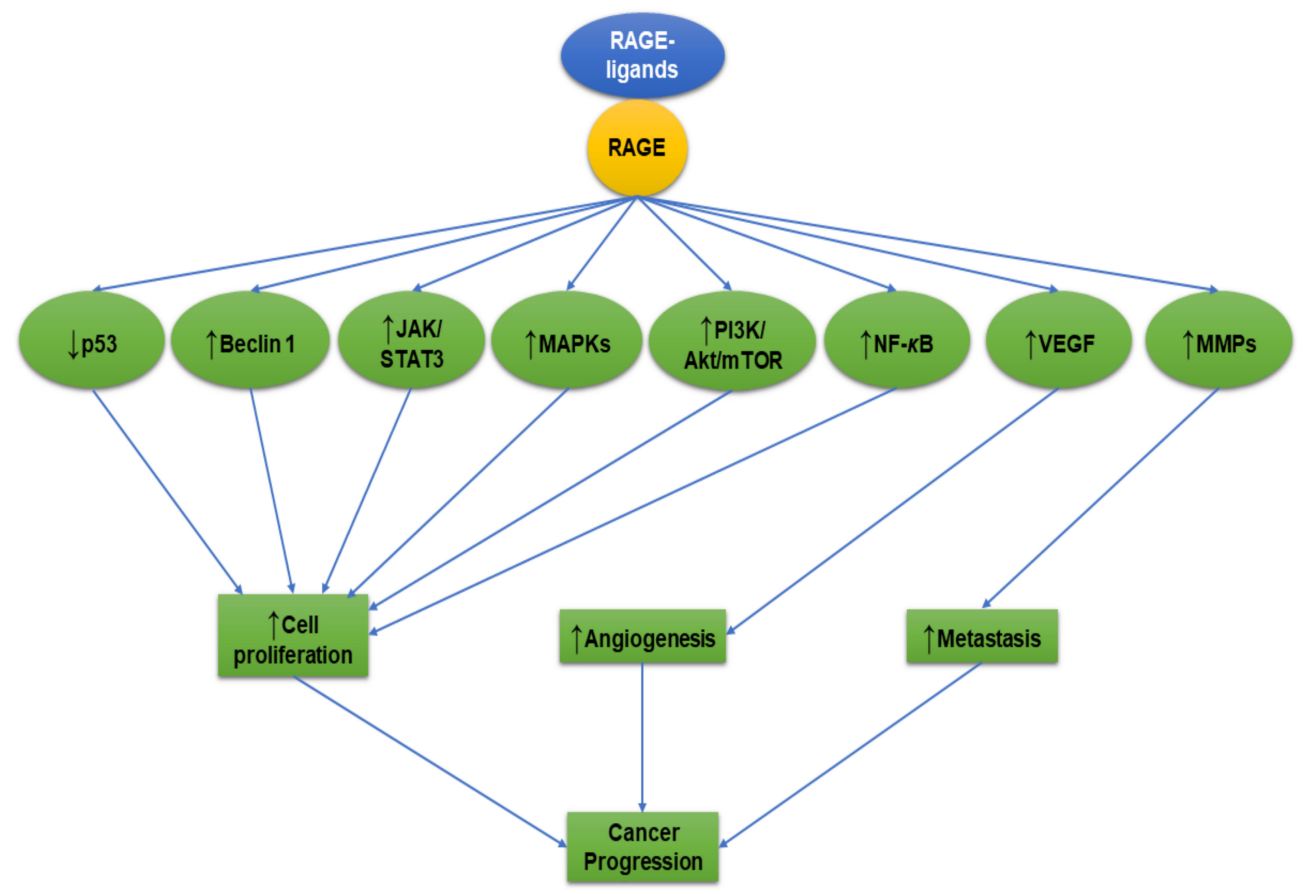

Figure 1. The effects of receptor for advanced glycation end product (RAGE)-ligands on cancer progression. The interaction between RAGE-ligands/RAGE results in upregulation of the phosphatidylinositide 3-kinase (PI3K)/protein kinase B (Akt)/mammalian target of rapamycin (mTOR), mitogen-activated protein kinases (MAPKs), matrix metalloproteinases (MMPs), vascular endothelial growth factor (VEGF), and nuclear factor kappa B (NF- $\kappa$ B) pathways and downregulation of p53. These pathways play an important role in controlling the tumor cells' proliferation, angiogenesis, and invasion. The arrow pointing up ( $\uparrow$ means increase or upregulation. The arrow pointing down $(\downarrow)$ means decrease or downregulation. 


\subsection{ChREBP}

The AGEs studies presented in Table 1 indicate that colorectal and hepatocellular carcinoma (HepG2) cells are the ones most affected by AGEs through upregulation of carbohydrate response element binding protein (ChREBP) [28]. ChREBP binds to the carbohydrate response element in the promoter of pyruvate kinase, the enzyme that is involved in the processes of glycolysis, lipogenesis, and gluconeogenesis [29]. This pivotal role of ChREBP in cancer progression might be due to the enhancement of anaerobic glucose metabolism and suppression of p53 that favors cancer growth [30].

\subsection{JAK/STAT3}

Janus kinase (JAK)/signal transducer and activator of transcription (STAT) signaling plays an important role in a variety of diseases, including cancer [31]. JAK/STAT can facilitate the transcription of genes involved in cancer cell proliferation [32]. The AGEs-RAGE axis-induced upregulation of STAT3 was observed in erythroleukemia [33] and breast adenocarcinoma [25].

\section{3. $M A P K$ and $M M P S$}

It was also established that after binding to RAGE, AGEs upregulated some MAPK pathways and related MAPK family members such as ERK, specificity protein 1 (Sp1), matrix metalloproteinase 2 (MMP2), MMP9, and p38 [13,25,27,34-37]. For example, after binding to RAGE, AGEs upregulated Sp1 expression via activating ERK pathway [34]. Notably, Sp1 can regulate many cellular molecules including MMP2, which can degrade type IV collagen to facilitate the metastasis of cancer cells [38], including human oral cancer (SAS) [39], gastric cancer cell line SGC7901 [34], and human colorectal cancer samples [35] via AGEs-RAGE axis. Moreover, another matrix metalloproteinase member, MMP9, which is upregulated by ERK after activation of AGEs-RAGE, is strongly associated with progression and metastatic breast and oral cancers [37,39].

\section{4. $\mathrm{Nrf}-2$}

Nuclear factor (erythroid-derived 2)-like 2 (Nrf-2): Keap1 complex could lead to cancer cell proliferation and metastasis through regulation of p53 apoptotic pathway $[23,40]$. Activated AGEs-RAGE axis in oral cancer (SAS) cell line led to downregulation of Nrf-2 that consequently facilitated the spread of cancer cells [23]. The authors postulated that downregulation of Nrf-2 is associated with the downregulation of p53 of oral cancer cells via heme oxygenase (HO-1). This finding is in accordance with the study of Lee et al. [41] who stated that downregulation of Nrf-2 led to downregulation of HO-1, consequently downregulating p53, and hindering apoptosis of oral cancer cells-thus favoring their progression.

\subsection{PI3K/Akt}

A number of different studies demonstrated that induction of AGEs led to upregulation of phosphatidylinositide 3-kinase (PI3K) [22,33], protein kinase B (Akt) [22], NF- $\kappa$ B [13,42-44], and VEGF [21,24] and downregulation of p53 [23] in various cancer cell types (Table 1). Based on these studies, we propose that activation of the AGEs-RAGE axis leads to upregulation of PI3K and subsequent phosphorylation of Akt. The aforementioned processes were accompanied by phosphorylation of Akt and enhanced the expressions of NF- $k \mathrm{~B}$, VEGF, and mouse double minute 2 homolog (MDM2). These three molecules protected the cancer cells from apoptosis. Overexpressed NF- $\kappa$ B resulted in increased cancer cells' proliferation and protected them from apoptosis. Upregulation of NF- $\kappa \mathrm{B}$ abrogated the activities of the caspases with cancer proliferation [45]. Moreover, the upregulated VEGF is known to be the key mediator of angiogenesis that forms the new blood vessels for nutrition and propagation of cancer cells [46]. Finally, phospho-Akt upregulated the MDM2 protein that consequently downregulated p53 tumor suppressor gene, leading to the termination of both intrinsic and extrinsic apoptotic pathways and favoring cancer cell proliferation. 
Table 1. Role of the advanced glycation end products (AGEs)-receptor for advanced glycation end product (RAGE) axis in cancer progression.

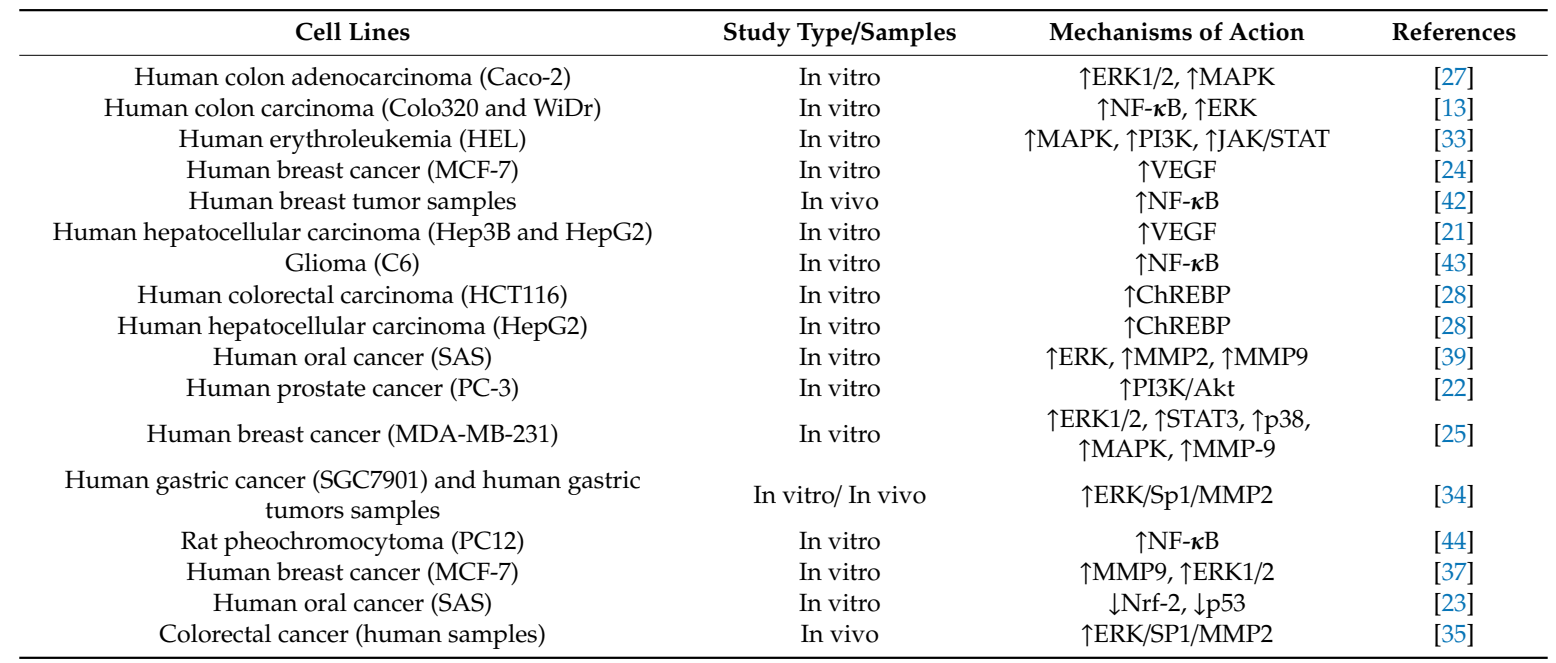

Akt; protein kinase B, ERK; extracellular signal-regulated kinase, JAK; Janus kinase, MAPK; mitogen-activated protein kinase, MMPs; matrix metalloproteinases, NF- $k \mathbf{B}$; nuclear factor kappa B, Nrf-2; Nuclear factor (erythroid-derived 2)-like 2, PI3K; phosphatidylinositide 3-kinase, STAT3; signal transducer and activator of transcription 3.The arrow pointing up $(\uparrow)$ means increase or upregulation. The arrow pointing down $(\downarrow)$ means decrease or downregulation.

\section{Mechanisms of HMGB1-RAGE Axis in Cancer Progression}

High-mobility group box1 (HMGB1) is a crucial factor in the development and progression of breast, colon, gastrointestinal, and liver cancers [12,47-49]. Binding of HMGB1 to RAGE has been associated with tumor cell survival, progression, and metastasis [50]. HMGB1 protects cells from apoptosis because it affects telomere stability and stimulates certain cellular proteins involved in the proliferation of cancer cells [51]. The effects of HMGB1 on RAGE and subsequent upregulation of certain anti-apoptotic molecules and downregulation of pro-apoptotic molecules in these studies are presented in Table 2. The mechanisms of their action are discussed next.

\subsection{Beclin-1}

Beclin-1 has been associated with cancer cell autophagy. However, Rohatgi and Shaw have determined that Beclin-1 induced tumor progression by regulation of growth factor receptor signaling in an autophagy-independent manner [52]. Beclin-1 regulated the epidermal growth factor and insulin-like growth factor-1, leading to activation of Akt and ERK in breast cancer cells [53]. In the same way, Beclin-1 was upregulated by AGEs and enhanced the progression and aggressiveness of human pancreatic cancer (Panc2.03) cell lines [54].

\subsection{MAPK}

Numerous studies have recognized the upregulation of the ERK/MAPK pathway by HMGB1 in colon carcinoma [13,55], renal cell carcinoma [56], liver carcinogenesis in mice [57], gastric carcinoma [58], hepatocellular carcinoma [59], breast adenocarcinoma (MCF-7) [55], and alveolar basal epithelial cells adenocarcinoma (A549) cells [55]. Upregulation of the ERK/MAPK pathway induced the survival and proliferation of those cells. Activation of ERK enhanced the expression of c-Myc that downregulated p21 and enhanced the cell cycle members cyclin-dependent kinase-2 (CDK-2) and cyclin D1 in hepatocellular carcinoma [59]. In addition, ERK upregulated MMP2 and MMP9, which led to cell proliferation and metastasis [60]. Other MAPK members have been upregulated by HMGB1 including cell division control protein 42 homolog (Cdc42)/Ras-related C3 botulinum toxin substrate 1 (Rac1)/mitogen-activated protein kinase kinase 6 (MKK6)/p38 that led to the proliferation of human rhabdomyosarcoma [61] and hepatocellular carcinoma [59]. Additionally, another member 
of MAPKs, stress-activated protein kinases (SAPK)/ c-Jun N-terminal kinase (JNK), has been shown to be upregulated due to the HMGB1-RAGE activation in glioma, murine Lewis lung carcinoma, and hepatocellular carcinoma (HCC) [59,62].

\subsection{MicroRNA}

MicroRNAs (miRNAs or miR) are small noncoding RNAs that participate in the regulation of diverse cell functions [63]. The abnormally regulated miRNAs have been shown to affect cancer proliferation, invasion, and metastasis [64]. HMGB1-RAGE axis upregulated miR-221/222 in thyroid carcinoma $[65,66]$. The re-regulated expression of miR-221 and miR-222 in thyroid carcinoma decreased p27(Kip1) protein levels, a major cell cycle regulator, which contributed to the advance of thyroid carcinoma in the S-phase [67]. In addition, miR-155-5p was transferred to colorectal cancer cells by macrophage-derived exosomes and downregulated expression of BRG1, the key factor promoting the colorectal cancer metastasis [68]. Therefore, upregulation of these miRNAs with HMGB1-RAGE helps cancer progression.

\subsection{MMPs}

MMPs are a group of proteolytic enzymes that degrade multiple extracellular matrix components to promote tumor invasion, angiogenesis and metastasis, and therefore they represent ideal pharmacologic targets for cancer therapy [69]. HMGB1 promoted the upregulation of MMPs (MMP1, MMP2, MMP3, MMP7, MMP9, and MMP10). Upregulation of MMPs with HMGB1 has been associated with cancer cell proliferation of colon [13,70], pancreatic [71], pulmonary [60], hepatocarcinoma [72], and hepatocellular carcinoma cell lines [59]. The upregulated MMPs are capable of degrading the components of the extracellular matrix and facilitating tumor progression [73].

\subsection{NF- $\kappa B /$ Snail}

HMGB1 upregulated NF- $\kappa$ B expression in human pancreatic (BxPC-3) [74], hepatocarcinoma (HUH 7 and H22) [14,72], fibrosarcoma (HT1080) [11,75], non-small cell lung cancer (NSCLC) [76], HCC [77], and breast adenocarcinoma (MCF-7) cells [78]. Overexpressed NF- $\kappa$ B upregulated Snail, which subsequently upregulated $\mathrm{N}$-cadherin [79] and vimentin [80]. $\mathrm{N}$-cadherin and vimentin favor the epithelial-mesenchymal cells transition and cancer cell migration. In addition, Snail-induced downregulation of E-cadherin [79] and phosphatase and tensin homolog (PTEN) resulted in cell proliferation and metastasis $[65,66]$.

\subsection{PI3K/Akt}

HMGB1 upregulated PI3K/Akt, which subsequently regulated various cellular proteins that induced cell proliferation and decreased apoptosis of cancer cells $[55,81,82]$. One of them is VEGF that overexpressed due to the increased level of HMGB1 in human oral squamous cell carcinoma (OSCC) [83,84] and bladder carcinoma [85], facilitating angiogenesis of cancer and its proliferation. In the same context, PI3K/Akt upregulation led to downregulation of pro-apoptotic molecules such as Bcl-2-associated X protein (Bax) and caspase-3 in human nasopharyngeal carcinoma (HONE-1) [86] and lung cancer cells (Lewis cells) [82]. 
Table 2. Role of the high-mobility group box1 (HMGB1-receptor for advanced glycation end product (RAGE) axis in cancer progression.

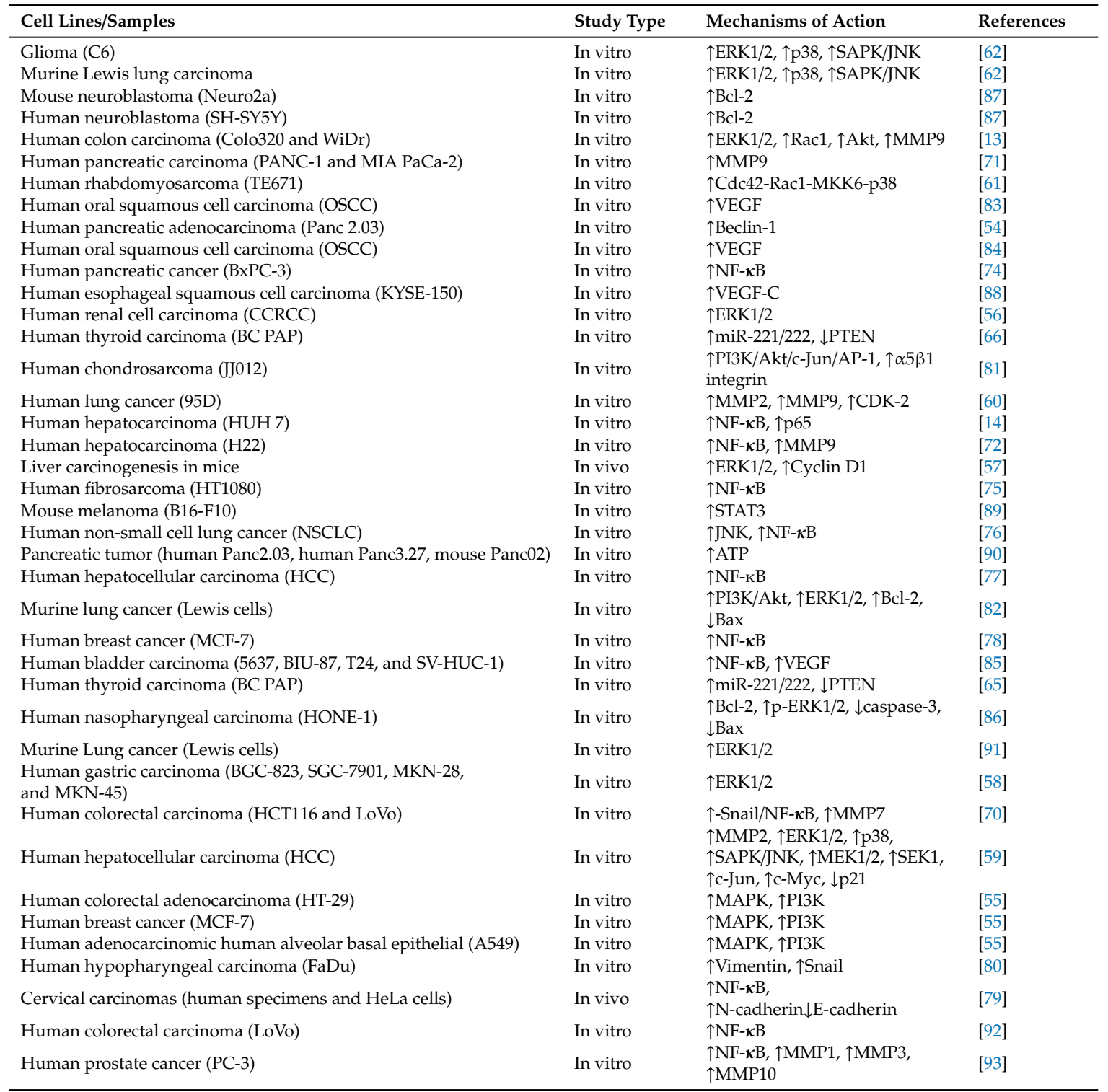

\footnotetext{
Akt; protein kinase B, AP-1; activator protein 1, ATP; adenosine triphosphate, Bax; Bcl-2-associated X protein, Bcl-2; B-cell lymphoma 2, Cdc42; cell division control protein 42 homolog, CDK-2; cyclin-dependent kinase-2, ERK; extracellular signal-regulated kinase, JNK; c-Jun N-terminal kinase, MKK6; mitogen-activated protein kinase kinase 6, MMPs; matrix metalloproteinases, NF- $\kappa \mathbf{B}$; nuclear factor kappa B, PI3K; phosphatidylinositide 3-kinase, PTEN; phosphatase and tensin homolog, Rac1; Ras-related C3 botulinum toxin substrate 1, SAPK; stress-activated protein kinases, STAT3; signal transducer and activator of transcription 3, VEGF; vascular endothelial growth factor, VEGF-C; vascular endothelial growth factor $C$. The arrow pointing up $(\uparrow)$ means increase or upregulation. The arrow pointing down $(\downarrow)$ means decrease or downregulation.
}

\section{Mechanisms of S100 Family-RAGE Axis in Cancer Progression}

S100 proteins are involved in many aspects of regulation of proliferation, differentiation, apoptosis, and inflammation [94]. Cancers exhibit a distinctive S100 protein as determined in human osteosarcoma, melanoma, pancreatic carcinoma, colorectal carcinoma, and breast adenocarcinoma [95-98]. The data in Table 3 show the possible mechanisms by which S100 proteins could induce cancer progression associated with the RAGE signaling pathway. These mechanisms are discussed below. 


\subsection{Angiogenesis}

Angiogenesis is defined as the formation of new blood vessels from preexisting vessels and has been characterized as an essential process for cancer cell proliferation and viability because it supplies the cancer cells with nutrients and oxygen [99]. Notably, VEGF is a protein involved in both vasculogenesis and angiogenesis leading to growth and metastasis of solid cancers [100]. Therefore, targeting of VEGF/vascular endothelial growth factor (VEGFR) signaling is a powerful approach to restrict cancer progression [99]. Some studies listed in Table 3 revealed downregulation of VEGF expression in response to S100s-RAGE binding in pancreatic, colorectal, and breast cancers [101-103].

\subsection{MAPK}

S100s members upregulated MAPK family members either ERK, Cdc42/p38, or SAPK/ JNK pathways that led to the progression of colorectal (HCT116, MC38, SW620, and DLD-1), thyroid (human specimens), nasopharyngeal (human specimens), breast (human specimens), and prostate (LNCaP and PC-3) cancers [95,104-109]. These resulted in cancer proliferation and progression.

\section{3. $M M P S$}

Molecular-based assessments of breast cancers have revealed expression of S100s, including S100A2, S100A4, and S100A7, with different expression levels during breast tumorigenesis and progression [110]. Nasser et al. [108] observed a relation between S100A7 and cancer progression of aggressive triple-negative breast cancer of human specimens and found upregulation of MMP9 due to S100A7. Moreover, MMP9 expression was increased in pancreatic carcinoma (BxPC3) [111] and nasopharyngeal carcinoma (C666-1) along with MMP2 [112] that was triggered by S100P. These results encourage researcher to control breast, pancreatic, and nasopharyngeal cancers through blockage of S100A7 and S100P-RAGE.

\section{4. $N F-\kappa B$}

Activation of RAGE by S100A4, S100A7, S100A8, S100A9, S100A14, S100B, and S100P was associated with upregulation of NF- $\kappa$ B that induced progression of different types of cancer including pancreatic, melanoma, breast, prostate, colon, neuroblastoma, and esophageal [74,97,106,108,113-115]. S100A4 upregulated E-cadherin $[101,116]$ that was regulated by NF- $\kappa \mathrm{B} /$ Snail and led to cancer metastasis. Thus, to understand the effects of cancer progression due to induction of the S100s family members through the NF- $\kappa$ B pathway, it is essential to study their effects on the inhibitors of apoptosis members (IAPs), B-cell lymphoma (Bcl-2), and Snail.

\section{5. $p 53$}

Because of stimulation of RAGE by the S100B in melanoma, lung, breast, colorectal, and ovarian cancers [117-120] by p53 downregulation that inhibited the intrinsic and extrinsic apoptotic pathways leading to cancer progression. In the aforementioned studies, the authors investigated the effects of S100B on p53, but they did not study the effect on the other members of intrinsic and extrinsic apoptotic pathways such as caspase- $-3,-8$, and -9 . Therefore, we propose that it is important to study the effect of S100B on intrinsic and extrinsic apoptotic pathway molecules. In addition, p53 regulated the cell cycle via p21. Recent data revealed that S100A16 caused significant decreases in p21 and p27 expressions in human prostate cancer and this promoted the cycle division of cancer cells [121].

\subsection{PI3K/Akt/mTOR}

The PI3K/Akt/mTOR pathway exists as one of the most attractive targets to block cancer progression [122]. This pathway has been upregulated by S100A4 in colorectal [101], S100A16 in prostate [121], and S100B in neuroblastoma cancers [113] with growth promotion caused by the anti-apoptosis and cell proliferation induced by the PI3K/Akt/mTOR pathway. 


\subsection{STAT3}

Diverse studies have demonstrated constitutive activation of STAT3 in a wide variety of human tumors including hematological malignancies and solid tumors inducing cell proliferation, angiogenesis, invasion, and metastasis [123]. This cancer progression effect of STAT3 has been recognized in glioma cells in response to S100B/RAGE [124,125]. STAT3 is a transcription factor that regulates the expression of genes related to cell cycle, cell survival, and cancer malignancy. Once STAT3 is activated, it translocate to the nucleus where it promotes the translation of target genes associated with anti-apoptosis, angiogenesis, invasion, and migration [126]. Finally, we can control some of STAT3 cancer progression through inhibition of the S100B-RAGE pathway.

Table 3. Role of the S100 family-receptor for advanced glycation end product (RAGE) axis in cancer progression.

\begin{tabular}{|c|c|c|c|c|}
\hline S100 Type & Cell Lines/Samples & Study Type & Mechanisms of Action & References \\
\hline \multirow{10}{*}{ S100A4 } & Human osteosarcoma (II-11b) & In vitro & $\uparrow N F-\kappa B$ & {$[96]$} \\
\hline & Human melanoma (A375) & In vitro & $\uparrow N F-\kappa B$ & [127] \\
\hline & Human pancreatic cancer (BxPC-3) & In vitro & $\uparrow N F-\kappa B$ & [74] \\
\hline & Human pancreatic carcinoma (MiaPACA-2) & In vitro & $\uparrow \mathrm{VEGF}$ & [103] \\
\hline & $\begin{array}{l}\text { Human colorectal carcinoma (HCT116, SW620, } \\
\text { and DLD-1) }\end{array}$ & In vitro & $\uparrow E R K$ & [95] \\
\hline & Human melanoma (B16-F10) & In vitro & $\uparrow N F-\kappa B$ & [97] \\
\hline & Human colorectal carcinoma (SW480 and LoVo) & In vitro & $\begin{array}{l}\uparrow A k t, \uparrow \mathrm{mTOR}, \uparrow \mathrm{p} 70 \mathrm{~S} 6 \mathrm{~K}, \\
\uparrow \mathrm{VEGF}, \downarrow \mathrm{E}-\mathrm{cadherin}\end{array}$ & [101] \\
\hline & Thyroid cancer (human specimens) & In vitro & $\uparrow C d c 42, \uparrow E R K$ & [109] \\
\hline & Human melanoma (A375) & In vitro & $\downarrow$ E-cadherin & [116] \\
\hline & Human melanoma (A375) & In vitro & $\uparrow N F-\kappa B$ & [128] \\
\hline S100A6 & Nasopharyngeal carcinoma (human specimens) & In vivo & $\uparrow$ p38 & {$[107]$} \\
\hline \multirow{3}{*}{ S100A7 } & Human breast adenocarcinoma (MDA-MB-468) & In vitro & $\uparrow$ VEGF & [102] \\
\hline & $\begin{array}{l}\text { Aggressive triple-negative breast cancer (human } \\
\text { specimens) }\end{array}$ & In vivo & $\uparrow E R K, \uparrow N F-\kappa B, \uparrow M M P 9$ & {$[108]$} \\
\hline & $\begin{array}{l}\text { Human cervical cancer derived (C33A, HeLa, } \\
\text { SiHa, and Caski) }\end{array}$ & In vitro & $\uparrow E R K$ & {$[129]$} \\
\hline \multirow{7}{*}{ S100A8 } & Human prostate cancer (LNCaP and PC-3) & In vitro & $\uparrow N F-\kappa B, \uparrow p 38, \uparrow E R K 1 / 2$ & [105] \\
\hline & Esophageal pre-neoplasia in the rat & In vivo & $\uparrow N F-\kappa B$ & [130] \\
\hline & Colon carcinoma (MC38) & In vitro & $\begin{array}{l}\uparrow N F-\kappa B, \uparrow E R K 1 / 2, \\
\uparrow S A P K / J N K\end{array}$ & [106] \\
\hline & Oral-esophageal tumor in mice & In vivo & $\uparrow N F-\kappa B$ & {$[114]$} \\
\hline & Human breast cancer (MCF-7 and T47D) & In vitro & $\uparrow N F-\kappa B$ & [98] \\
\hline & Hepatocellular carcinoma in mice & In vivo & $\uparrow E R K$ & [131] \\
\hline & Squamous cell carcinoma (human specimens) & In vivo & $\begin{array}{l}\uparrow \mathrm{p} 38, \uparrow \mathrm{SAPK} / \mathrm{JNK}, \\
\uparrow \mathrm{ERK} 1 / 2\end{array}$ & {$[132]$} \\
\hline \multirow{6}{*}{ S100A9 } & Human prostate cancer (LNCaP and PC-3) & In vitro & $\uparrow N F-\kappa B, \uparrow p 38, \uparrow E R K 1 / 2$ & [105] \\
\hline & Colon carcinoma (MC38) & In vitro & $\begin{array}{l}\uparrow N F-\kappa B, \uparrow E R K 1 / 2, \\
\uparrow S A P K / J N K\end{array}$ & [106] \\
\hline & Human breast cancer (MCF-7 and T47D) & In vitro & $\uparrow N F-\kappa B$ & [98] \\
\hline & Hepatocellular carcinoma in mice & In vivo & $\uparrow E R K$ & [131] \\
\hline & Squamous cell carcinoma (human specimens) & In vivo & $\begin{array}{l}\uparrow p 38, \uparrow S A P K / J N K, \\
\uparrow E R K 1 / 2\end{array}$ & {$[132]$} \\
\hline & $\begin{array}{l}\text { Human hepatocellular carcinoma (HepG2, } \\
\text { SMMC-7721 and Huh7) }\end{array}$ & In vitro & $\uparrow p-p 38, \uparrow p-E R K 1 / 2$ & {$[133]$} \\
\hline S100A14 & Esophageal squamous cell carcinoma (KYSE180) & In vitro & $\uparrow E R K 1 / 2, \uparrow N F-\kappa B$ & [115] \\
\hline S100A16 & $\begin{array}{l}\text { Human prostate cancer (DU-145, LNCaP, } \\
\text { and PC-3) }\end{array}$ & In vitro & $\uparrow \mathrm{Akt}, \uparrow \mathrm{ERK}, \downarrow \mathrm{p} 21, \downarrow \mathrm{p} 27$ & {$[121]$} \\
\hline
\end{tabular}


Table 3. Cont.

\begin{tabular}{|c|c|c|c|c|}
\hline S100 Type & Cell Lines/Samples & Study Type & Mechanisms of Action & References \\
\hline \multirow{10}{*}{ S100B } & Human melanoma (WM115) & In vitro & $\downarrow$ p53 & [119] \\
\hline & Human large cell lung carcinoma (H1299) & In vitro & $\downarrow$ p53 & [117] \\
\hline & Human breast cancer (MCF-7) & In vitro & $\downarrow \mathrm{p} 53$ & [117] \\
\hline & Human colorectal carcinoma (SW480) & In vitro & $\uparrow E R K 1 / 2$ & [134] \\
\hline & Human malignant melanoma (C8146A) & In vitro & $\downarrow$ p53 & [118] \\
\hline & Human neuroblastoma (SH-SY5Y) & In vitro & $\uparrow \mathrm{PI} 3 \mathrm{~K} / \mathrm{Akt}, \uparrow \mathrm{NF}-\kappa \mathrm{B}$ & [113] \\
\hline & Human malignant melanoma (C8146A) & In vitro & $\downarrow \mathrm{p} 53$ & [135] \\
\hline & Murine glioma (GL261) & In vitro & 个STAT3 & [125] \\
\hline & Ovarian cancer stem-like cell & In vitro & $\downarrow$ p53 & [120] \\
\hline & Glioma (C6) & In vitro & $\uparrow \mathrm{Akt1}, \uparrow \mathrm{STAT} 3$ & [124] \\
\hline \multirow{8}{*}{ S100P } & $\begin{array}{l}\text { Human pancreatic adenocarcinoma (BxPC-3 and } \\
\text { MPanc-96) }\end{array}$ & In vitro & $\uparrow N F-\kappa B$ & [136] \\
\hline & Human colon cancer (SW480) & In vitro & $\uparrow N F-\kappa B, \uparrow E R K 1 / 2$ & {$[104]$} \\
\hline & Human pancreatic cancer (BxPC-3) & In vitro & $\uparrow N F-\kappa B$ & {$[74]$} \\
\hline & $\begin{array}{l}\text { Human colorectal carcinoma (LS174T and } \\
\text { SW480) }\end{array}$ & In vitro & $\uparrow \mathrm{miR}-155$ & {$[137]$} \\
\hline & Human pancreatic carcinoma (BxPC3) & In vitro & $\uparrow \mathrm{MMP9}$ & [111] \\
\hline & Human oral squamous cell carcinoma (OSCC) & In vitro & $\uparrow N F-\kappa B$ & {$[138]$} \\
\hline & $\begin{array}{l}\text { Human colorectal carcinoma (SW480 and } \\
\text { LS174T) }\end{array}$ & In vitro & $\uparrow c-F o s, \uparrow A P-1, \uparrow \mathrm{miR}-21$ & {$[139]$} \\
\hline & Human nasopharyngeal carcinoma (C666-1) & In vitro & $\uparrow \mathrm{MMP} 2, \uparrow \mathrm{MMP9}$ & [112] \\
\hline
\end{tabular}

Akt; protein kinase B, AP-1; activator protein 1, Cdc42; cell division control protein 42 homolog, ERK; extracellular signal-regulated kinase, JNK; c-Jun N-terminal kinase, MMPs; matrix metalloproteinases, mTOR; mammalian target of rapamycin, NF- $\boldsymbol{k B}$; nuclear factor kappa B, p70S6K; ribosomal protein S6 kinase B1, SAPK; stress-activated protein kinases, STAT3; signal transducer and activator of transcription 3, VEGF; vascular endothelial growth factor.The arrow pointing up $(\uparrow)$ means increase or upregulation. The arrow pointing down $(\downarrow)$ means decrease or downregulation.

\section{RAGE-Inhibitors}

RAGE signaling blocking in cell and animal models has shown that targeting RAGE affects the development and metastasis of cancer [140]. As discussed above, the pivotal role of RAGE in cancer progression caused by the induction of several cellular pathways is related to either cancer cell proliferation, migration, invasion, or metastasis. The goal of some studies was to discover new drugs able to alleviate or block the cancer progression. Still, these problems require further investigations. The respective studies are listed in Table 4 and discussed in the following paragraphs.

\subsection{Duloxetine}

Cancer is often mixed with neuropathic pain. For this reason, frequently in patients with cancer-related neuropathic pain opioids such as anticonvulsants (e.g. pregabalin and gabapentin) and antidepressants (e.g. duloxetine and tricyclics) are used [141]. Duloxetine is a serotonin/noradrenaline reuptake inhibitor that is used as an antidepressant and is also prescribed for neuropathic pain [142] (Figure 2). There are a few studies that used duloxetine for chemotherapy-induced peripheral neuropathy [143]. Gao et al. [144] searched for S100B-inhibitors using a high-throughput screening cell-based S100B promoter-driven luciferase reporter assay. The authors treated mouse glioma cells (GL261) with duloxetine at a dose of $30 \mathrm{mg} / \mathrm{kg}$ by oral gavage for 14 days and determined that duloxetine inhibited S100B production and inhibited the growth of intracranial GL261 gliomas. These findings affirm the role of S100B in glioma progression. Thus, we think that it is important to develop more potent S100B-inhibitors for glioma therapy. 


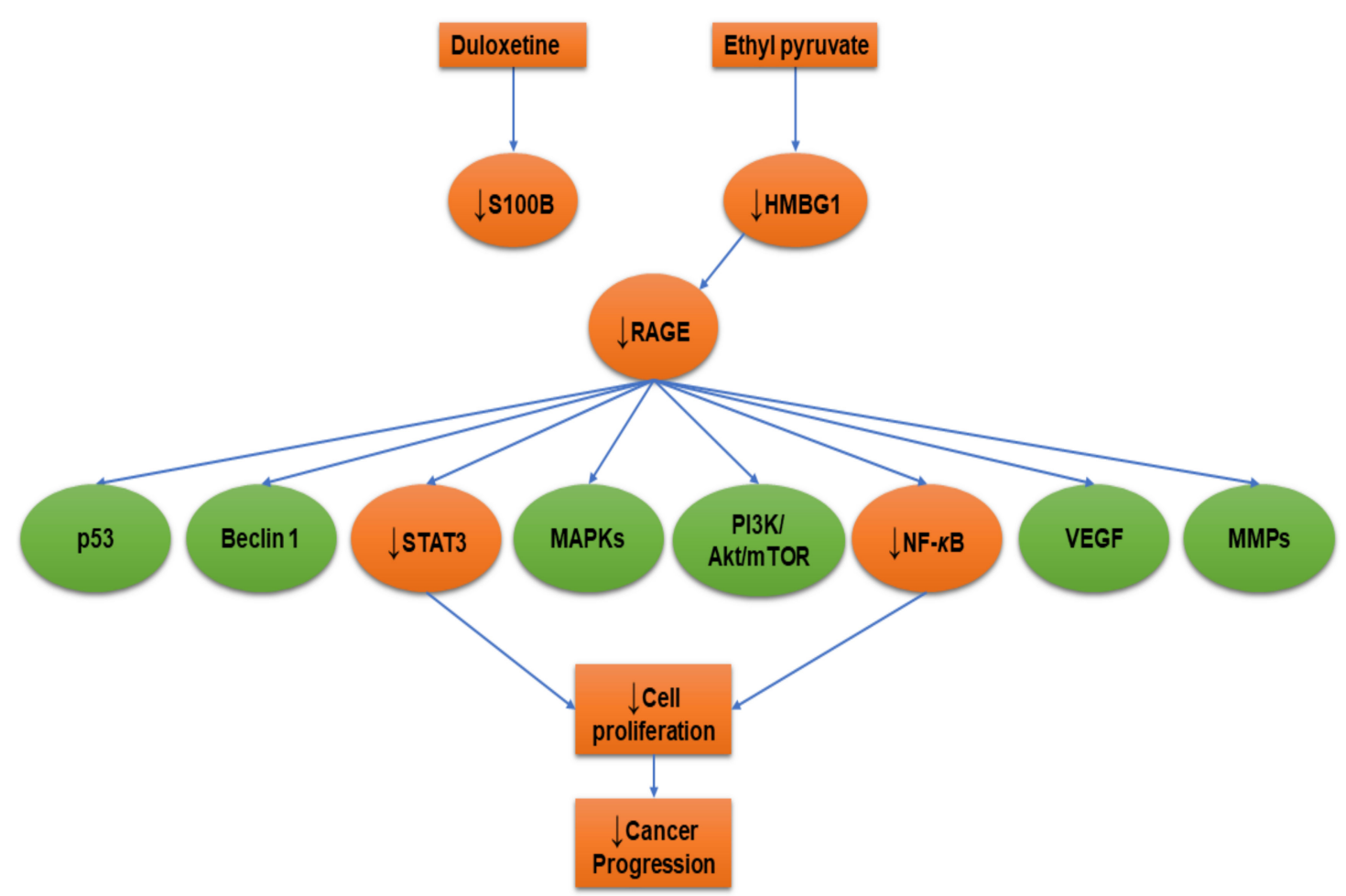

Figure 2. Receptor for advanced glycation end product (RAGE) inhibition with duloxetine and ethyl pyruvate. Orange colored shapes refer to the affected cellular molecules due to RAGE inhibition. The arrow pointing down $(\downarrow)$ means decrease or downregulation.

\subsection{Ethyl Pyruvate}

Ethyl pyruvate, the ethyl ester of pyruvic acid), has been shown to be an effective HMGB1-inhibitor in inflammation-related diseases and several cancers [145,146]. Pellegrini et al. [145] studied the effect of ethyl pyruvate on human malignant mesothelioma cells in tissue cultures and on tumor growth in vivo. The authors established that there was a significant impairment of HMGB1 secretion by malignant mesothelioma cells due to ethyl pyruvate, leading to reduction in RAGE expression and NF- $\kappa$ B activation. Moreover, ethyl pyruvate reduced HMGB1 serum levels in mice and inhibited the growth of malignant mesothelioma xenografts. Therefore, ethyl pyruvate is an effective drug for malignant mesothelioma. In another in vitro study, ethyl pyruvate attenuated the non-small cell lung cancer cell lines growth, invasion, and migration and induced apoptosis via the downregulation of HMGB1-RAGE axis and the NF- $\kappa$ B/STAT3 pathway [147] as illustrated in Figure 2.

\subsection{Hispidin}

Natural plant products can be important for developing drug products. Hispidin is a polyphenol compound derived from Phellinus linteus and it has several biological activities such as antioxidant [148] and anticancer [149]. Hispidin could be a new gemcitabine chemosensitizer and potentially a synergistic agent to increase the gemcitabine therapeutic index to treat pancreatic cancer [150]. In addition, hispidin significantly induced apoptosis in colon cancer cells by generation of reactive oxygen species (ROS) [149]. Rat pheochromocytoma (PC12) cells were pre-incubated with $2 \mu \mathrm{M}$ of ergothioneine, thiol molecule synthesized by some fungi and bacteria, hispidin, or a combination of them. The results revealed a significant attenuation of AGEs' formation, RAGE expression, and NF- $\kappa$ B pathway activation through antioxidant activities [44]. Both the antioxidant compounds ergothioneine and hispidin counteracted the AGEs-RAGE axis-related induction of carcinogenesis (Figure 3). 


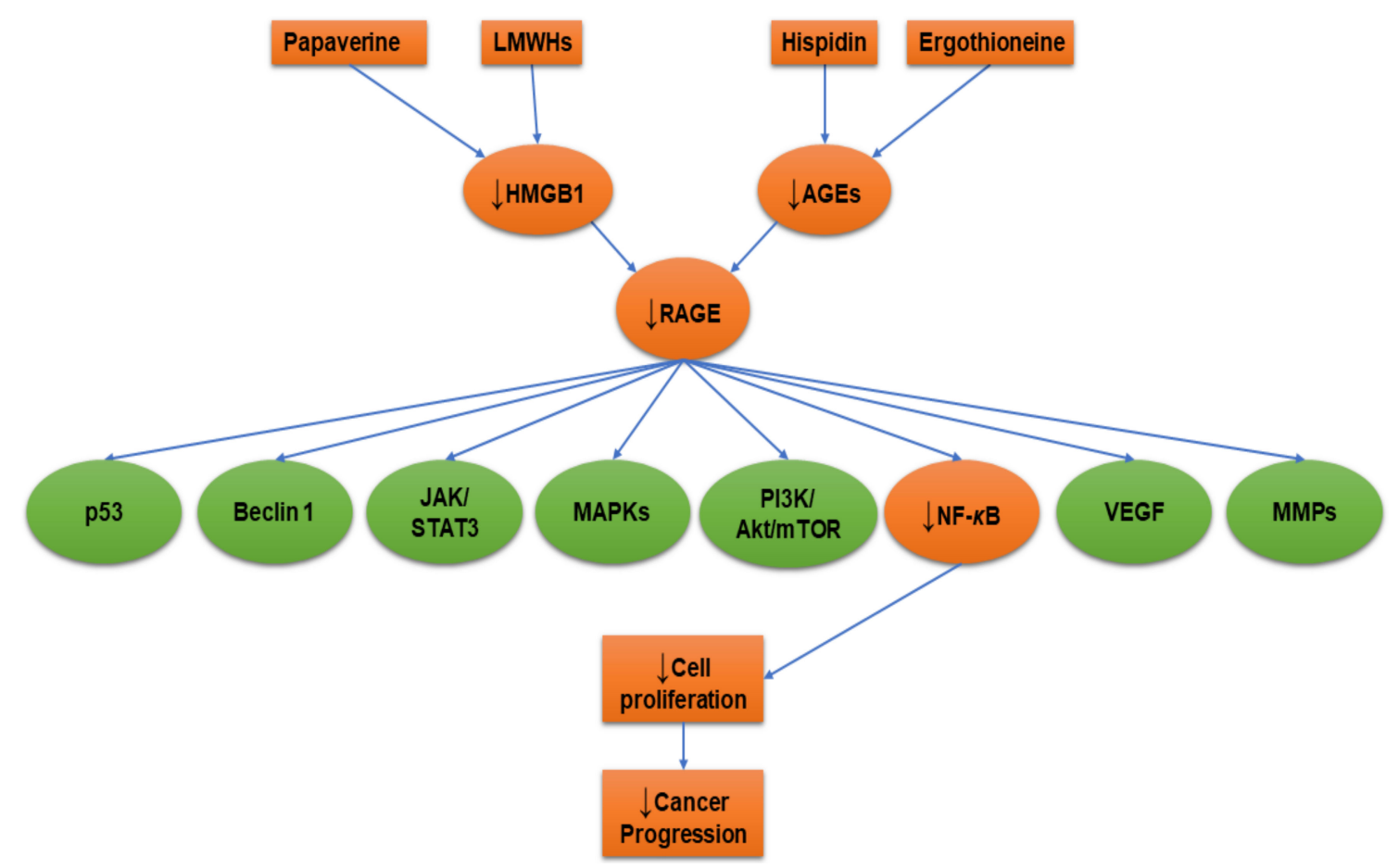

Figure 3. Receptor for advanced glycation end product (RAGE) inhibition with hispidin, ergothioneine, low-molecular-weight heparins (LMWHs), and papaverine. Orange colored shapes refer to the affected cellular molecules due to RAGE inhibition. The arrow pointing down $(\downarrow)$ means decrease or downregulation.

\subsection{Heparin}

The low-molecular-weight heparins (LMWHs) are an old class of anti-thrombotic drugs and tend to be the preferred anticoagulant in many indices that are important for modern hematology and oncology with patients who are at elevated risk of both hemorrhage and venous thromboembolism [151]. LMWH attenuated the HMGB1-induced NF- $\kappa$ B activation through RAGE using an NF- $\kappa$ B-dependent luciferase reporter assay and the HT1080 cell line. LMWH significantly inhibited the migration, invasion, tumor formation, and lung metastasis of HT1080 RAGE cells, but not of HT1080 ${ }^{\text {mock }}$ or HT1080 ${ }^{\text {dnRAGE }}$ cells [75] (Figure 3). The authors suggested that LMWH has therapeutic potential in patients with certain types of malignant tumors. In the same manner, chondroitin sulfate and heparan sulfate targeted RAGE and significantly decreased pulmonary metastasis [152].

\subsection{Papaverine}

Papaverine, a non-narcotic opium alkaloid, is isolated from Papaver somniferum. Papaverine exhibited selective anticancer effects against several tumor cells [11,153]. An in vitro study was done to investigate the anti-RAGE effect of papaverine, optimized by the structure-based drug design system named conversion-to-small-molecules-through optimized-peptide strategy (COSMOS), in HT1080 human fibrosarcoma cells. Using RAGE- or dominant-negative RAGE-expressing HT1080 human fibrosarcoma cells, papaverine suppressed RAGE-dependent HT1080 human fibrosarcoma cell proliferation, migration, and invasion in a dose-dependent manner through a significant inhibition of RAGE-dependent NF- $\kappa$ B driven by HMGB1 [11] (Figure 3). Furthermore, papaverine downregulated HMGB1 and RAGE along with significant inhibition of cell proliferation in human glioblastoma (U87MG and T98G) cell lines [153]. Therefore, papaverine could inhibit RAGE and is considered to be a promising anticancer drug. 
Table 4. Receptor for advanced glycation end product (RAGE)-inhibitors that attenuated cancer progression.

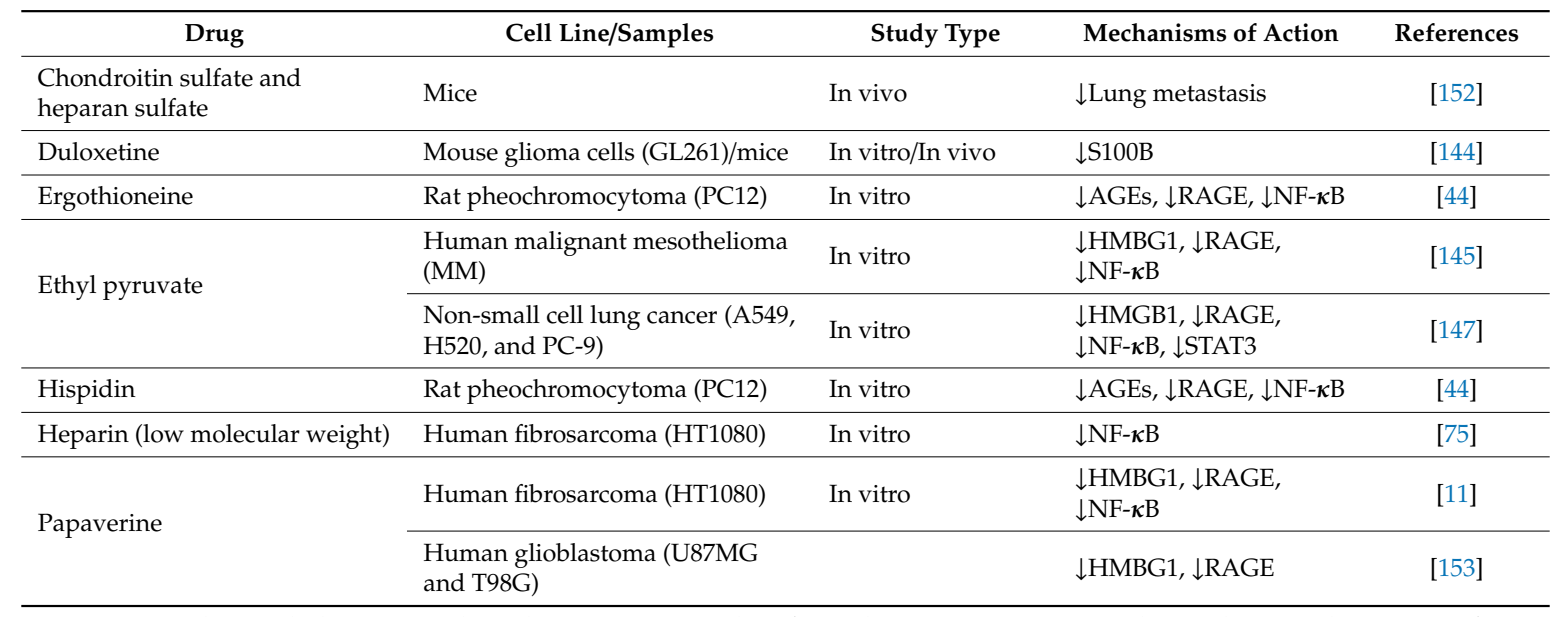

AGEs; advanced glycation end products, NF-kB; nuclear factor kappa B, STAT3; signal transducer and activator of transcription 3 RAGE; receptor for advanced glycation end product.The arrow pointing up $(\uparrow)$ means increase or upregulation. The arrow pointing down $(\downarrow)$ means decrease or downregulation.

\section{Conclusions}

From the studies reviewed here, it can be concluded that RAGE-ligand complexes induce upregulation of an array of anti-apoptotic proteins and downregulate pro-apoptotic proteins to promote cancer cell progression, as illustrated in Figure 1. It is essential to screen for new anti-RAGE drugs with capabilities to control cancer progression. For further characterization of the effects of RAGE-ligands on cancer progression and for development of better treatments, we propose the following study points for consideration:

- Comparative studies of RAGE-ligands.

- The role of RAGE-ligands in cancer progression in primary cell culture of surgically removed tumor masses or cancer biopsies.

- The role of RAGE-ligands in cancer progression using cancer stem cells.

- The role of AGEs in colorectal cancer with therapeutic trials.

- Studies of the effect of RAGE-ligands' pathway signaling on intrinsic pathway components such as cytochrome c, apoptotic protease activating factor 1 (Apaf-1), caspase-9, and caspase-3.

- Studies of the effect of RAGE-ligands' pathway signaling on extrinsic pathway components such as tumor necrosis factor receptor-associated death domain (TRADD), Fas-associated death domain (FADD), caspase-8, and caspase-10.

- Studies of the effect of RAGE-ligands' pathway signaling on Bcl-2 family, either the pro-apoptotic (BAX, BID, BAK, or BAD) or anti-apoptotic (Bcl-Xl and Bcl-2).

- Studies of the effect of RAGE-ligands' pathway signaling on molecules that induce cell survival and metastasis including E-cadherin, hypoxia-inducible factor 1-alpha (HIF-1 $\alpha$ ), PTEN, and MDM2.

- Studies of the effect of RAGE-ligands' pathway signaling on cyclin-dependent kinases (CDK-1, 2, 4 , or 6) and regulatory cyclin subunits (cyclin A, B, Ds, or E).

- Studies of the effect of RAGE-ligands' pathway signaling on molecules that facilitate cell survival and metastasis such as $\beta$-catenin, epidermal growth factor receptor (EGFR), VEGF, and vimentin.

- Discovery of new drugs that downregulate RAGE and its ligands to control cancer progression.

- The role of RAGE-ligands in cancer senescence and senotherapies.

Funding: No funding was received. 
Acknowledgments: We appreciate Kelly Keating, Pharmaceutical Research Institute (PRI) for her excellent editing of this manuscript.

Conflicts of Interest: The authors declare no potential conflicts of interest.

\section{Abbreviations}

$\begin{array}{ll}\text { Akt } & \text { protein kinase B } \\ \text { AP-1 } & \text { activator protein 1 } \\ \text { Apaf-1 } & \text { apoptotic protease activating factor 1 } \\ \text { ATP } & \text { adenosine triphosphate } \\ \text { Bad } & \text { Bcl-2-associated death promoter, } \\ \text { Bak } & \text { Bcl-2 homologous antagonist/killer } \\ \text { Bax } & \text { Bcl-2-associated X protein } \\ \text { Bcl-2; } & \text { B-cell lymphoma 2 } \\ \text { Bcl-XL } & \text { B-cell lymphoma-extra-large } \\ \text { Cdc42 } & \text { cell division control protein 42 homolog } \\ \text { CDK-1 } & \text { cyclin-dependent kinase-1 } \\ \text { CDK-2 } & \text { cyclin-dependent kinase-2 } \\ \text { CDK-4 } & \text { cyclin-dependent kinase-4 } \\ \text { CDK-6 } & \text { cyclin-dependent kinase-6 } \\ \text { ChREBP } & \text { carbohydrate responsive element binding protein } \\ \text { EGFR } & \text { epidermal growth factor receptor } \\ \text { ERK } & \text { extracellular signal-regulated kinase } \\ \text { FADD } & \text { Fas-associated death domain } \\ \text { HIF-1 } \alpha & \text { hypoxia-inducible factor 1-alpha } \\ \text { HMGB1 } & \text { high-mobility group box1 } \\ \text { JAK } & \text { Janus kinase } \\ \text { JNK } & \text { c-Jun N-terminal kinase } \\ \text { MAPK } & \text { mitogen-activated protein kinase } \\ \text { MDM2 } & \text { mouse double minute 2 homolog } \\ \text { MKK6 } & \text { mitogen-activated protein kinase kinase 6 } \\ \text { MMPs } & \text { matrix metalloproteinases } \\ \text { mTOR } & \text { mammalian target of rapamycin, } \\ \text { Nrf-2 } & \text { Nuclear factor (erythroid-derived 2)-like 2 } \\ \text { NF- } \kappa \text { B } & \text { nuclear factor kappa B } \\ \text { p70S6K } & \text { ribosomal protein S6 kinase B1 } \\ \text { PI3K } & \text { phosphatidylinositide 3-kinase } \\ \text { PTEN } & \text { phosphatase and tensin homolog } \\ \text { Rac1 } & \text { Ras-related C3 botulinum toxin substrate 1 } \\ \text { RAGE } & \text { receptor of advanced glycation end product } \\ \text { ROS } & \text { reactive oxygen species } \\ \text { SAPK } & \text { stress-activated protein kinases } \\ \text { STAT3 } & \text { signal transducer and activator of transcription 3 } \\ \text { TRADD } & \text { tumor necrosis factor receptor-associated death domain } \\ \text { VEGF } & \text { vascular endothelial growth factor } \\ \text { VEGF-C } & \text { vascular endothelial growth factor C. } \\ & \end{array}$

\section{References}

1. Iwamura, M.; Yamamoto, Y.; Kitayama, Y.; Higuchi, K.; Fujimura, T.; Hase, T.; Yamamoto, H. Epidermal expression of receptor for advanced glycation end products (RAGE) is related to inflammation and apoptosis in human skin. Exp. Dermatol. 2016, 25, 235-237. [CrossRef] [PubMed]

2. López-Díez, R.; Rastrojo, A.; Villate, O.; Aguado, B. Complex Tissue-Specific Patterns and Distribution of Multiple RAGE Splice Variants in Different Mammals. Genome Biol. Evol. 2013, 5, 2420-2435. [CrossRef] [PubMed] 
3. Hudson, B.I.; Carter, A.M.; Harja, E.; Kalea, A.Z.; Arriero, M.; Yang, H.; Grant, P.J.; Schmidt, A.M. Identification, classification, and expression of RAGE gene splice variants. FASEB J. 2008, 22, 1572-1580. [CrossRef] [PubMed]

4. Ding, Q.; Keller, J.N. Evaluation of rage isoforms, ligands, and signaling in the brain. Biochim. Biophys. Acta Mol. Cell Res. 2005, 1746, 18-27. [CrossRef] [PubMed]

5. Oury, T.D.; Li, Y.; Liu, S.; Zhang, Z.; Xu, Q.; Xie, F.; Wang, J.; Ping, S.; Li, C.; Wang, Z.; et al. RAGE Mediates Accelerated Diabetic Vein Graft Atherosclerosis Induced by Combined Mechanical Stress and AGEs via Synergistic ERK Activation. PLoS ONE 2012, 7, e35016. [CrossRef]

6. He, M.; Kubo, H.; Morimoto, K.; Fujino, N.; Suzuki, T.; Takahasi, T.; Yamada, M.; Yamaya, M.; Maekawa, T.; Yamamoto, Y.; et al. Receptor for advanced glycation end products binds to phosphatidylserine and assists in the clearance of apoptotic cells. EMBO Rep. 2011, 12, 358-364. [CrossRef]

7. Win, M.T.T.; Yamamoto, Y.; Munesue, S.; Saito, H.; Han, D.; Motoyoshi, S.; Kamal, T.; Ohara, T.; Watanabe, T.; Yamamoto, H.; et al. Regulation of RAGE for attenuating progression of diabetic vascular complications. Exp. Diabetes Res. 2012, 2012, 894605. [CrossRef]

8. Yan, S.D.; Chen, X.; Fu, J.; Chen, M.; Zhu, H.; Roher, A.; Slattery, T.; Zhao, L.; Nagashima, M.; Morser, J.; et al. RAGE and amyloid- $\beta$ peptide neurotoxicity in Alzheimer's disease. Nature 1996, 382, 685-691. [CrossRef]

9. Huttunen, H.J.; Fages, C.; Rauvala, H. Receptor for advanced glycation end products (RAGE)-mediated neurite outgrowth and activation of NF-kappaB require the cytoplasmic domain of the receptor but different downstream signaling pathways. J. Biol. Chem. 1999, 274, 19919-19924. [CrossRef]

10. Lander, H.M.; Tauras, J.M.; Ogiste, J.S.; Hori, O.; Moss, R.A.; Schmidt, A.M. Activation of the receptor for advanced glycation end products triggers a p21(ras)-dependent mitogen-activated protein kinase pathway regulated by oxidant stress. J. Biol. Chem. 1997, 272, 17810-17814. [CrossRef]

11. El-Far, A.; Munesue, S.; Harashima, A.; Sato, A.; Shindo, M.; Nakajima, S.; Inada, M.; Tanaka, M.; Takeuchi, A.; Tsuchiya, H.; et al. In vitro anticancer effects of a RAGE inhibitor discovered using a structure-based drug design system. Oncol. Lett. 2018, 15, 4627-4634. [CrossRef] [PubMed]

12. Flohr, A.M.; Rogalla, P.; Meiboom, M.; Borrmann, L.; Krohn, M.; Thode-Halle, B.; Bullerdiek, J. Variation of HMGB1 expression in breast cancer. Anticancer Res. 2001, 21, 3881-3885. [PubMed]

13. Kuniyasu, H.; Chihara, Y.; Kondo, H. Differential effects between amphoterin and advanced glycation end products on colon cancer cells. Int. J. Cancer 2003, 104. [CrossRef] [PubMed]

14. Yaser, A.-M.; Huang, Y.; Zhou, R.-R.; Hu, G.-S.; Xiao, M.-F.; Huang, Z.-B.; Duan, C.-J.; Tian, W.; Tang, D.-L.; Fan, X.-G. The Role of Receptor for Advanced Glycation End Products (RAGE) in the Proliferation of Hepatocellular Carcinoma. Int. J. Mol. Sci. 2012, 13, 5982-5997. [CrossRef] [PubMed]

15. Reed, J.; Jurgensmeier, J.; Matsuyama, S. Bcl-2 family proteins and mitochondria. Biochim. Biophys. Acta Bioenerg. 1998, 1366, 127-137. [CrossRef]

16. El-Far, A.H.; Badria, F.A.; Shaheen, H.M. Possible Anticancer Mechanisms of Some Costus speciosus Active Ingredients Concerning Drug Discovery. Curr. Drug Discov. Technol. 2016, 13, 123-143. [CrossRef]

17. Evan, G.I.; Vousden, K.H. Proliferation, cell cycle and apoptosis in cancer. Nature 2001, 411, $342-348$. [CrossRef]

18. Kang, R.; Tang, D.; Lotze, M.T.; Zeh, H.J. RAGE regulates autophagy and apoptosis following oxidative injury. Autophagy 2011, 7, 442-444. [CrossRef]

19. Ahmed, N. Advanced glycation endproducts-Role in pathology of diabetic complications. Diabetes Res. Clin. Pract. 2005, 67, 3-21. [CrossRef]

20. Peyroux, J.; Sternberg, M. Advanced glycation endproducts (AGEs): Pharmacological inhibition in diabetes. Pathol. Biol. 2006, 54, 405-419. [CrossRef]

21. Takino, J.; Yamagishi, S.; Takeuchi, M. Glycer-AGEs-RAGE signaling enhances the angiogenic potential of hepatocellular carcinoma by upregulating VEGF expression. World J. Gastroenterol. 2012, 18, 1781-1788. [CrossRef] [PubMed]

22. Bao, J.-M.; He, M.-Y.; Liu, Y.-W.; Lu, Y.-J.; Hong, Y.-Q.; Luo, H.-H.; Ren, Z.-L.; Zhao, S.-C.; Jiang, Y. AGE/RAGE/Akt pathway contributes to prostate cancer cell proliferation by promoting Rb phosphorylation and degradation. Am. J. Cancer Res. 2015, 5, 1741-1750. [CrossRef] [PubMed]

23. Ko, S.-Y.; Ko, H.-A.; Shieh, T.-M.; Chi, T.-C.; Chen, H.-I.; Chen, Y.-T.; Yu, Y.-H.; Yang, S.-H.; Chang, S.-S. Advanced glycation end products influence oral cancer cell survival via Bcl-xl and Nrf-2 regulation In Vitro. Oncol. Lett. 2017, 13, 3328-3334. [CrossRef] [PubMed] 
24. Ishibashi, Y.; Matsui, T.; Takeuchi, M.; Yamagishi, S. Metformin Inhibits Advanced Glycation End Products (AGEs)-induced Growth and VEGF Expression in MCF-7 Breast Cancer Cells by Suppressing AGEs Receptor Expression via AMP-activated Protein Kinase. Horm. Metab. Res. 2012, 45, 387-390. [CrossRef]

25. Sharaf, H.; Matou-Nasri, S.; Wang, Q.; Rabhan, Z.; Al-Eidi, H.; Al Abdulrahman, A.; Ahmed, N. Advanced glycation endproducts increase proliferation, migration and invasion of the breast cancer cell line MDA-MB-231. Biochim. Biophys. Acta Mol. Basis Dis. 2015, 1852, 429-441. [CrossRef]

26. Wang, X.; Yu, S.; Wang, C.-Y.; Wang, Y.; Liu, H.-X.; Cui, Y.; Zhang, L.-D. Advanced glycation end products induce oxidative stress and mitochondrial dysfunction in SH-SY5Y cells. Vitr. Cell. Dev. Biol. Anim. 2014, 51, 204-209. [CrossRef]

27. Zill, H.; Günther, R.; Erbersdobler, H.F.; Fölsch, U.R.; Faist, V. RAGE Expression and AGE-Induced MAP Kinase Activation in Caco-2 Cells. Biochem. Biophys. Res. Commun. 2001, 288, 1108-1111. [CrossRef]

28. Chen, H.; Wu, L.; Li, Y.; Meng, J.; Lin, N.; Yang, D.; Zhu, Y.; Li, X.; Li, M.; Xu, Y.; et al. Advanced glycation end products increase carbohydrate responsive element binding protein expression and promote cancer cell proliferation. Mol. Cell. Endocrinol. 2014, 395, 69-78. [CrossRef]

29. Iizuka, K.; Horikawa, Y. ChREBP: A Glucose-activated Transcription Factor Involved in the Development of Metabolic Syndrome. Endocr. J. 2008, 55, 617-624. [CrossRef]

30. Tong, X.; Zhao, F.; Mancuso, A.; Gruber, J.J.; Thompson, C.B. The glucose-responsive transcription factor ChREBP contributes to glucose-dependent anabolic synthesis and cell proliferation. Proc. Natl. Acad. Sci. USA 2009, 106, 21660-21665. [CrossRef]

31. Aaronson, D.S. A Road Map for Those Who Don't Know JAK-STAT. Science 2002, 296, 1653-1655. [CrossRef]

32. Thomas, S.J.; Snowden, J.A.; Zeidler, M.P.; Danson, S.J. The role of JAK/STAT signalling in the pathogenesis, prognosis and treatment of solid tumours. Br. J. Cancer 2015, 113, 365-371. [CrossRef] [PubMed]

33. Kim, J.Y.; Park, H.K.; Yoon, J.S.; Kim, S.J.; Kim, E.S.; Ahn, K.S.; Kim, D.-S.; Yoon, S.S.; Kim, B.K.; Lee, Y.Y. Advanced glycation end product (AGE)-induced proliferation of HEL cells via receptor for AGE-related signal pathways. Int. J. Oncol. 2008, 33, 493-501. [CrossRef] [PubMed]

34. Deng, R.; Mo, F.; Chang, B.; Zhang, Q.; Ran, H.; Yang, S.; Zhu, Z.; Hu, L.; Su, Q. Glucose-derived AGEs enhance human gastric cancer metastasis through RAGE/ERK/Sp1/MMP2 cascade. Oncotarget 2017, 8, 104216-104226. [CrossRef] [PubMed]

35. Deng, R.; Wu, H.; Ran, H.; Kong, X.; Hu, L.; Wang, X.; Su, Q. Glucose-derived AGEs promote migration and invasion of colorectal cancer by up-regulating Sp1 expression. Biochim. Biophys. Acta Gen. Subj. 2017, 1861, 1065-1074. [CrossRef] [PubMed]

36. Hudson, B.I.; Kalea, A.Z.; del Mar Arriero, M.; Harja, E.; Boulanger, E.; D’Agati, V.; Schmidt, A.M. Interaction of the RAGE Cytoplasmic Domain with Diaphanous-1 Is Required for Ligand-stimulated Cellular Migration through Activation of Rac1 and Cdc42. J. Biol. Chem. 2008, 283, 34457-34468. [CrossRef]

37. Matou-Nasri, S.; Sharaf, H.; Wang, Q.; Almobadel, N.; Rabhan, Z.; Al-Eidi, H.; Yahya, W.B.; Trivilegio, T.; Ali, R.; Al-Shanti, N.; et al. Biological impact of advanced glycation endproducts on estrogen receptor-positive MCF-7 breast cancer cells. Biochim. Biophys. Acta Mol. Basis Dis. 2017, 1863, 2808-2820. [CrossRef]

38. Mook, O.R.F.; Frederiks, W.M.; Van Noorden, C.J.F. The role of gelatinases in colorectal cancer progression and metastasis. Biochim. Biophys. Acta Rev. Cancer 2004, 1705, 69-89. [CrossRef]

39. Ko, S.S.-Y.; Ko, H.-A.; Shieh, T.-M.; Chang, W.-C.; Chen, H.-I.; Chang, S.S.-S.; Lin, I.-H.; Ahmad, S.K.; Moinuddin, D.; Shahab, U.; et al. Cell Migration Is Regulated by AGE-RAGE Interaction in Human Oral Cancer Cells In Vitro. PLoS ONE 2014, 9, e110542. [CrossRef]

40. Sajadimajd, S.; Khazaei, M. Oxidative Stress and Cancer: The Role of Nrf2. Curr. Cancer Drug Targets 2018, 18, 538-557. [CrossRef]

41. Lee, Y.-M.; Auh, Q.-S.; Lee, D.-W.; Kim, J.-Y.; Jung, H.-J.; Lee, S.-H.; Kim, E.-C. Involvement of Nrf2-Mediated Upregulation of Heme Oxygenase-1 in Mollugin-Induced Growth Inhibition and Apoptosis in Human Oral Cancer Cells. Biomed Res. Int. 2013, 2013, 1-14. [CrossRef] [PubMed]

42. Korwar, A.M.; Bhonsle, H.S.; Chougale, A.D.; Kote, S.S.; Gawai, K.R.; Ghole, V.S.; Koppikar, C.B.; Kulkarni, M.J. Analysis of AGE modified proteins and RAGE expression in HER2/neu negative invasive ductal carcinoma. Biochem. Biophys. Res. Commun. 2012, 419, 490-494. [CrossRef] [PubMed]

43. Munesue, S.; Yamamoto, Y.; Urushihara, R.; Inomata, K.; Saito, H.; Motoyoshi, S.; Watanabe, T.; Yonekura, H.; Yamamoto, H. Low-molecular weight fractions of Japanese soy sauce act as a RAGE antagonist via inhibition of RAGE trafficking to lipid rafts. Food Funct. 2013, 4, 1835. [CrossRef] [PubMed] 
44. Song, T.-Y.; Yang, N.-C.; Chen, C.-L.; Thi, T.L.V. Protective Effects and Possible Mechanisms of Ergothioneine and Hispidin against Methylglyoxal-Induced Injuries in Rat Pheochromocytoma Cells. Oxid. Med. Cell. Longev. 2017, 2017, 1-10. [CrossRef] [PubMed]

45. Sheikh, M.S.; Huang, Y. Death Receptor Activation Complexes: It Takes Two to Activate TNF Receptor 1. Cell Cycle 2014, 2, 549-551. [CrossRef]

46. Carmeliet, P. VEGF as a Key Mediator of Angiogenesis in Cancer. Oncology 2005, 69, 4-10. [CrossRef]

47. Choi, Y.R.; Kim, H.; Kang, H.J.; Kim, N.-G.; Kim, J.J.; Park, K.-S.; Paik, Y.-K.; Kim, H.O.; Kim, H. Overexpression of high mobility group box 1 in gastrointestinal stromal tumors with KIT mutation. Cancer Res. 2003, 63, 2188-2193.

48. Volp, K.; Völp, K.; Brezniceanu, M.-L.; Bösser, S.; Brabletz, T.; Kirchner, T.; Göttel, D.; Joos, S.; Zörnig, M. Increased expression of high mobility group box 1 (HMGB1) is associated with an elevated level of the antiapoptotic c-IAP2 protein in human colon carcinomas. Gut 2006, 55, 234-242. [CrossRef]

49. Yan, W.; Chang, Y.; Liang, X.; Cardinal, J.S.; Huang, H.; Thorne, S.H.; Monga, S.P.S.; Geller, D.A.; Lotze, M.T.; Tsung, A. High-mobility group box 1 activates caspase- 1 and promotes hepatocellular carcinoma invasiveness and metastases. Hepatology 2012, 55, 1863-1875. [CrossRef]

50. Zhang, Q.-B.; Jia, Q.; Wang, H.; Hu, C.-X.; Sun, D.; Jiang, R.-D.; Zhang, Z.-L.; El-Serag, H.; Rudolph, K.; Rampone, B.; et al. High-mobility group protein box1 expression correlates with peritumoral macrophage infiltration and unfavorable prognosis in patients with hepatocellular carcinoma and cirrhosis. BMC Cancer 2016, 16, 880. [CrossRef]

51. Smolarczyk, R.; Cichoń, T.; Jarosz, M.; Szala, S. HMGB1-Its role in tumor progression and anticancer therapy. Postepy Hig. Med. Dosw. 2012, 66, 913-920. [CrossRef] [PubMed]

52. Rohatgi, R.A.; Shaw, L.M. An autophagy-independent function of Beclin 1 in cancer. Mol. Cell. Oncol. 2016, 3, e1030539. [CrossRef] [PubMed]

53. Rohatgi, R.A.; Janusis, J.; Leonard, D.; Bellvé, K.D.; Fogarty, K.E.; Baehrecke, E.H.; Corvera, S.; Shaw, L.M. Beclin 1 regulates growth factor receptor signaling in breast cancer. Oncogene 2015, 34, 5352-5362. [CrossRef] [PubMed]

54. Tang, D.; Kang, R.; Cheh, C.-W.; Livesey, K.M.; Liang, X.; Schapiro, N.E.; Benschop, R.; Sparvero, L.J.; Amoscato, A.A.; Tracey, K.J.; et al. HMGB1 release and redox regulates autophagy and apoptosis in cancer cells. Oncogene 2010, 29, 5299-5310. [CrossRef]

55. Sharma, S.; Evans, A.; Hemers, E. Mesenchymal-epithelial signalling in tumour microenvironment: Role of high-mobility group Box 1. Cell Tissue Res. 2016, 365, 357-366. [CrossRef]

56. Lin, L.; Zhong, K.; Sun, Z.; Wu, G.; Ding, G. Receptor for advanced glycation end products (RAGE) partially mediates HMGB1-ERKs activation in clear cell renal cell carcinoma. J. Cancer Res. Clin. Oncol. 2012, 138, 11-22. [CrossRef]

57. Pusterla, T.; Nèmeth, J.; Stein, I.; Wiechert, L.; Knigin, D.; Marhenke, S.; Longerich, T.; Kumar, V.; Arnold, B.; Vogel, A.; et al. Receptor for advanced glycation endproducts (RAGE) is a key regulator of oval cell activation and inflammation-associated liver carcinogenesis in mice. Hepatology 2013, 58, 363-373. [CrossRef]

58. Zhang, Q.Y.; Wu, L.Q.; Zhang, T.; Han, Y.F.; Lin, X. Autophagy-mediated HMGB1 release promotes gastric cancer cell survival via RAGE activation of extracellular signal-regulated kinases 1/2. Oncol. Rep. 2015, 33, 1630-1638. [CrossRef]

59. Chen, Y.; Lin, C.; Liu, Y.; Jiang, Y. HMGB1 promotes HCC progression partly by downregulating p21 via ERK/c-Myc pathway and upregulating MMP-2. Tumour Biol. 2016, 37, 4399-4408. [CrossRef]

60. Wang, C.; Fei, G.; Liu, Z.; Li, Q.; Xu, Z.; Ren, T. HMGB1 was a pivotal synergistic effecor for CpG oligonucleotide to enhance the progression of human lung cancer cells. Cancer Biol. Ther. 2012, 13, 727-736. [CrossRef]

61. Riuzzi, F.; Sorci, G.; Donato, R. RAGE expression in rhabdomyosarcoma cells results in myogenic differentiation and reduced proliferation, migration, invasiveness, and tumor growth. Am. J. Pathol. 2007, 171, 947-961. [CrossRef] [PubMed]

62. Taguchi, A.; Blood, D.C.; del Toro, G.; Canet, A.; Lee, D.C.; Qu, W.; Tanji, N.; Lu, Y.; Lalla, E.; Fu, C.; et al. Blockade of RAGE-amphoterin signalling suppresses tumour growth and metastases. Nature 2000, 405, 354-360. [CrossRef] [PubMed]

63. Ranganathan, K.; Sivasankar, V. MicroRNAs-Biology and clinical applications. J. Oral Maxillofac. Pathol. 2014, 18, 229-234. [CrossRef] [PubMed] 
64. Peng, Y.; Croce, C.M. The role of MicroRNAs in human cancer. Signal Transduct. Target. Ther. 2016, 1, 15004. [CrossRef]

65. Mardente, S.; Mari, E.; Massimi, I.; Fico, F.; Faggioni, A.; Pulcinelli, F.; Antonaci, A.; Zicari, A. HMGB1-Induced Cross Talk between PTEN and miRs 221/222 in Thyroid Cancer. Biomed Res. Int. 2015, 2015, 1-7. [CrossRef]

66. Mardente, S.; Mari, E.; Consorti, F.; Di Gioia, C.; Negri, R.; Etna, M.; Zicari, A.; Antonaci, A. HMGB1 induces the overexpression of miR-222 and miR-221 and increases growth and motility in papillary thyroid cancer cells. Oncol. Rep. 2012, 28, 2285-2289. [CrossRef]

67. Jikuzono, T.; Kawamoto, M.; Yoshitake, H.; Kikuchi, K.; Akasu, H.; Ishikawa, H.; Hirokawa, M.; Miyauchi, A.; Tsuchiya, S.; Shimizu, K.; et al. The miR-221/222 cluster, miR-10b and miR-92a are highly upregulated in metastatic minimally invasive follicular thyroid carcinoma. Int. J. Oncol. 2013, 42, 1858-1868. [CrossRef]

68. Lan, J.; Sun, L.; Xu, F.; Liu, L.; Hu, F.; Song, D.; Hou, Z.; Wu, W.; Luo, X.; Wang, J.; et al. M2 macrophage-derived exosomes promote cell migration and invasion in colon cancer. Cancer Res. 2019, 79, 146-158. [CrossRef]

69. Winer, A.; Adams, S.; Mignatti, P. Matrix metalloproteinase inhibitors in cancer therapy: Turning past failures into future successes. Mol. Cancer Ther. 2018, 17, 1147-1155. [CrossRef]

70. Zhu, L.; Li, X.; Chen, Y.; Fang, J.; Ge, Z. High-mobility group Box 1: A novel inducer of the epithelial-mesenchymal transition in colorectal carcinoma. Cancer Lett. 2015, 357, 527-534. [CrossRef]

71. Takada, M.; Hirata, K.; Ajiki, T.; Suzuki, Y.; Kuroda, Y. Expression of receptor for advanced glycation end products (RAGE) and MMP-9 in human pancreatic cancer cells. Hepatogastroenterology 2004, 51, 928-930. [PubMed]

72. Gong, W.; Wang, Z.-Y.; Chen, G.-X.; Liu, Y.-Q.; Gu, X.-Y.; Liu, W.-W. Invasion potential of H22 hepatocarcinoma cells is increased by HMGB1-induced tumor NF-кB signaling via initiation of HSP70. Oncol. Rep. 2013, 30, 1249-1256. [CrossRef] [PubMed]

73. Saarialho-Kere, U.K.; Chang, E.S.; Welgus, H.G.; Parks, W.C. Distinct localization of collagenase and tissue inhibitor of metalloproteinases expression in wound healing associated with ulcerative pyogenic granuloma. J. Clin. Invest. 1992, 90, 1952-1957. [CrossRef] [PubMed]

74. Arumugam, T.; Ramachandran, V.; Gomez, S.B.; Schmidt, A.M.; Logsdon, C.D. S100P-derived RAGE antagonistic peptide reduces tumor growth and metastasis. Clin. Cancer Res. 2012, 18, 4356-4364. [CrossRef] [PubMed]

75. Takeuchi, A.; Yamamoto, Y.; Munesue, S.; Harashima, A.; Watanabe, T.; Yonekura, H.; Yamamoto, H.; Tsuchiya, H. Low molecular weight heparin suppresses receptor for advanced glycation end products-mediated expression of malignant phenotype in human fibrosarcoma cells. Cancer Sci. 2013, 104, 740-749. [CrossRef] [PubMed]

76. Wu, X.; Mi, Y.; Yang, H.; Hu, A.; Zhang, Q.; Shang, C. The activation of HMGB1 as a progression factor on inflammation response in normal human bronchial epithelial cells through RAGE/JNK/NF-kB pathway. Mol. Cell. Biochem. 2013, 380, 249-257. [CrossRef]

77. Chen, R.; Yi, P.; Zhou, R.; Xiao, M.; Huang, Z.; Tang, D.; Huang, Y.; Fan, X. The role of HMGB1-RAGE axis in migration and invasion of hepatocellular carcinoma cell lines. Mol. Cell. Biochem. 2014, 390, 271-280. [CrossRef]

78. Dhumale, S.S.; Waghela, B.N.; Pathak, C. Quercetin protects necrotic insult and promotes apoptosis by attenuating the expression of RAGE and its ligand HMGB1 in human breast adenocarcinoma cells. IUBMB Life 2015, 67, 361-373. [CrossRef]

79. Pang, X.; Zhang, Y.; Zhang, S. High-mobility group box 1 is overexpressed in cervical carcinoma and promotes cell invasion and migration in vitro. Oncol. Rep. 2017, 37, 831-840. [CrossRef]

80. Li, Y.; Wang, P.; Zhao, J.; Li, H.; Liu, D.; Zhu, W. HMGB1 attenuates TGF- $\beta$-induced epithelial-mesenchymal transition of FaDu hypopharyngeal carcinoma cells through regulation of RAGE expression. Mol. Cell. Biochem. 2017, 431, 1-10. [CrossRef]

81. Tang, C.-H.; Keng, Y.-T.; Liu, J.-F. HMGB-1 induces cell motility and $\alpha 5 \beta 1$ integrin expression in human chondrosarcoma cells. Cancer Lett. 2012, 322, 98-106. [CrossRef] [PubMed]

82. Xu, X.; Zhu, H.; Wang, T.; Sun, Y.; Ni, P.; Liu, Y.; Tian, S.; Amoah Barnie, P.; Shen, H.; Xu, W.; et al. Exogenous High-Mobility Group Box 1 Inhibits Apoptosis and Promotes the Proliferation of Lewis Cells via RAGE/TLR4-Dependent Signal Pathways. Scand. J. Immunol. 2014, 79, 386-394. [CrossRef] [PubMed] 
83. Sasahira, T.; Kirita, T.; Oue, N.; Bhawal, U.K.; Yamamoto, K.; Fujii, K.; Ohmori, H.; Luo, Y.; Yasui, W.; Bosserhoff, A.K.; et al. High mobility group box-1-inducible melanoma inhibitory activity is associated with nodal metastasis and lymphangiogenesis in oral squamous cell carcinoma. Cancer Sci. 2008, 99, 1806-1812. [CrossRef] [PubMed]

84. Sasahira, T.; Yamamoto, K.; Kurihara, M.; Bhawal, U.K.; Chihara, Y.; Kirita, T.; Kuniyasu, H. The roles of HMGB1 related angiogenesis and lymphangiogenesis in oral cancer. Oncol. Rev. 2010, 5, 49-55. [CrossRef]

85. Huang, Z.; Zhong, Z.; Zhang, L.; Wang, X.; Xu, R.; Zhu, L.; Wang, Z.; Hu, S.; Zhao, X.; Babjuk, M.; et al. Down-regulation of HMGB1 expression by shRNA constructs inhibits the bioactivity of urothelial carcinoma cell lines via the NF-кB pathway. Sci. Rep. 2015, 5, 12807. [CrossRef] [PubMed]

86. Peng, T.; Hu, M.; Wu, T.; Chen, Z.; Zhang, C.; Huang, S.; Zhou, X. Effects of high-mobility group box 1 knockdown on proliferation, migration and invasion of the HONE-1 human nasopharyngeal carcinoma cell line. Mol. Med. Rep. 2015, 12, 7531-7537. [CrossRef]

87. Sajithlal, G.; Huttunen, H.; Rauvala, H.; Munch, G. Receptor for Advanced Glycation End Products Plays a More Important Role in Cellular Survival than in Neurite Outgrowth during Retinoic Acid-induced Differentiation of Neuroblastoma Cells. J. Biol. Chem. 2002, 277, 6888-6897. [CrossRef]

88. Chen, C.; Tang, P.; Yu, Z. [Effect of HMGB1 on the VEGF-C expression and proliferation of esophageal squamous cancer cells]. Zhonghua Zhong Liu Za Zhi 2012, 34, 566-570.

89. Tang, Q.; Li, J.; Zhu, H.; Li, P.; Zou, Z.; Xiao, Y. Hmgb1-IL-23-IL-17-IL-6-Stat3 Axis Promotes Tumor Growth in Murine Models of Melanoma. Mediators Inflamm. 2013, 2013, 1-13. [CrossRef]

90. Kang, R.; Tang, D.; Schapiro, N.E.; Loux, T.; Livesey, K.M.; Billiar, T.R.; Wang, H.; Van Houten, B.; Lotze, M.T.; Zeh, H.J. The HMGB1/RAGE inflammatory pathway promotes pancreatic tumor growth by regulating mitochondrial bioenergetics. Oncogene 2013, 33, 567-577. [CrossRef]

91. Su, Z.; Wang, T.; Zhu, H.; Zhang, P.; Han, R.; Liu, Y.; Ni, P.; Shen, H.; Xu, W.; Xu, H. HMGB1 modulates Lewis cell autophagy and promotes cell survival via RAGE-HMGB1-Erk1/2 positive feedback during nutrient depletion. Immunobiology 2015, 220, 539-544. [CrossRef] [PubMed]

92. Huang, M.; Geng, Y.; Deng, Q.; Li, R.; Shao, X.; Zhang, Z.; Xu, W.; Wu, Y.; Ma, Q. Translationally controlled tumor protein affects colorectal cancer metastasis through the high mobility group box 1-dependent pathway. Int. J. Oncol. 2018, 53, 1149-1481. [CrossRef] [PubMed]

93. Zhang, J.; Shao, S.; Han, D.; Xu, Y.; Jiao, D.; Wu, J.; Yang, F.; Ge, Y.; Shi, S.; Li, Y.; et al. High mobility group box 1 promotes the epithelial-to-mesenchymal transition in prostate cancer PC3 cells via the RAGE/NF- $\kappa B$ signaling pathway. Int. J. Oncol. 2018, 53, 659-671. [CrossRef] [PubMed]

94. Bresnick, A.R.; Weber, D.J.; Zimmer, D.B. S100 proteins in cancer. Nat. Rev. Cancer 2015, 15, 96-109. [CrossRef]

95. Dahlmann, M.; Okhrimenko, A.; Marcinkowski, P.; Osterland, M.; Herrmann, P.; Smith, J.; Heizmann, C.W.; Schlag, P.M.; Stein, U. RAGE mediates S100A4-induced cell motility via MAPK/ERK and hypoxia signaling and is a prognostic biomarker for human colorectal cancer metastasis. Oncotarget 2014, 5, 3220-3233. [CrossRef]

96. Grotterød, I.; Mælandsmo, G.M.; Boye, K. Signal transduction mechanisms involved in S100A4-induced activation of the transcription factor NF-kB. BMC Cancer 2010, 10, 241. [CrossRef]

97. Haase-Kohn, C.; Wolf, S.; Herwig, N.; Mosch, B.; Pietzsch, J. Metastatic potential of B16-F10 melanoma cells is enhanced by extracellular S100A4 derived from RAW264.7 macrophages. Biochem. Biophys. Res. Commun. 2014, 446, 143-148. [CrossRef]

98. Yin, C.; Li, H.; Zhang, B.; Liu, Y.; Lu, G.; Lu, S.; Sun, L.; Qi, Y.; Li, X.; Chen, W. RAGE-binding S100A8/A9 promotes the migration and invasion of human breast cancer cells through actin polymerization and epithelial-mesenchymal transition. Breast Cancer Res. Treat. 2013, 142, 297-309. [CrossRef]

99. Ramjiawan, R.R.; Griffioen, A.W.; Duda, D.G. Anti-angiogenesis for cancer revisited: Is there a role for combinations with immunotherapy? Angiogenesis 2017, 20, 185-204. [CrossRef]

100. Ferrara, N. Vascular Endothelial Growth Factor as a Target for Anticancer Therapy. Oncologist 2004, 9, 2-10. [CrossRef]

101. Wang, H.; Duan, L.; Zou, Z.; Li, H.; Yuan, S.; Chen, X.; Zhang, Y.; Li, X.; Sun, H.; Zha, H.; et al. Activation of the PI3K/Akt/mTOR/p70S6K Pathway is Involved in S100A4-induced Viability and Migration in Colorectal Cancer Cells. Int. J. Med. Sci. 2014, 11, 841-849. [CrossRef] [PubMed] 
102. Shubbar, E.; Vegfors, J.; Carlström, M.; Petersson, S.; Enerbäck, C. Psoriasin (S100A7) increases the expression of ROS and VEGF and acts through RAGE to promote endothelial cell proliferation. Breast Cancer Res. Treat. 2011, 134, 71-80. [CrossRef] [PubMed]

103. Hernández, J.L.; Padilla, L.; Dakhel, S.; Coll, T.; Hervas, R.; Adan, J.; Masa, M.; Mitjans, F.; Martinez, J.M.; Coma, S.; et al. Therapeutic Targeting of Tumor Growth and Angiogenesis with a Novel Anti-S100A4 Monoclonal Antibody. PLoS ONE 2013, 8, e72480. [CrossRef]

104. Fuentes, M.K.; Nigavekar, S.S.; Arumugam, T.; Logsdon, C.D.; Schmidt, A.M.; Park, J.C.; Huang, E.H. RAGE Activation by S100P in Colon Cancer Stimulates Growth, Migration, and Cell Signaling Pathways. Dis. Colon Rectum 2007, 50, 1230-1240. [CrossRef]

105. Hermani, A.; De Servi, B.; Medunjanin, S.; Tessier, P.A.; Mayer, D. S100A8 and S100A9 activate MAP kinase and NF-kappaB signaling pathways and trigger translocation of RAGE in human prostate cancer cells. Exp. Cell Res. 2006, 312, 184-197. [CrossRef]

106. Ichikawa, M.; Williams, R.; Wang, L.; Vogl, T.; Srikrishna, G. S100A8/A9 Activate Key Genes and Pathways in Colon Tumor Progression. Mol. Cancer Res. 2011, 9, 133-148. [CrossRef]

107. Li, A.; Shi, D.; Xu, B.; Wang, J.; Tang, Y.-L.; Xiao, W.; Shen, G.; Deng, W.; Zhao, C. S100A6 promotes cell proliferation in human nasopharyngeal carcinoma via the p38/MAPK signaling pathway. Mol. Carcinog. 2017, 56, 972-984. [CrossRef]

108. Nasser, M.W.; Wani, N.A.; Ahirwar, D.K.; Powell, C.A.; Ravi, J.; Elbaz, M.; Zhao, H.; Padilla, L.; Zhang, X.; Shilo, K.; et al. RAGE mediates S100A7-induced breast cancer growth and metastasis by modulating the tumor microenvironment. Cancer Res. 2015, 75, 974-985. [CrossRef]

109. Medapati, M.R.; Dahlmann, M.; Ghavami, S.; Pathak, K.A.; Lucman, L.; Klonisch, T.; Hoang-Vu, C.; Stein, U.; Hombach-Klonisch, S. RAGE Mediates the Pro-Migratory Response of Extracellular S100A4 in Human Thyroid Cancer Cells. Thyroid 2015, 25, 514-527. [CrossRef]

110. Emberley, E.D.; Murphy, L.C.; Watson, P.H. S100A7 and the progression of breast cancer. Breast Cancer Res. 2004, 6, 153-159. [CrossRef]

111. Dakhel, S.; Padilla, L.; Adan, J.; Masa, M.; Martinez, J.M.; Roque, L.; Coll, T.; Hervas, R.; Calvis, C.; Messeguer, R.; et al. S100P antibody-mediated therapy as a new promising strategy for the treatment of pancreatic cancer. Oncogenesis 2014, 3, e92. [CrossRef] [PubMed]

112. Liu, Y.; Wang, C.; Shan, X.; Wu, J.; Liu, H.; Liu, H.; Zhang, J.; Xu, W.; Sha, Z.; He, J.; et al. S100P is associated with proliferation and migration in nasopharyngeal carcinoma. Oncol. Lett. 2017, 14, 525-532. [CrossRef] [PubMed]

113. Leclerc, E.; Fritz, G.; Weibel, M.; Heizmann, C.W.; Galichet, A. S100B and S100A6 Differentially Modulate Cell Survival by Interacting with Distinct RAGE (Receptor for Advanced Glycation End Products) Immunoglobulin Domains. J. Biol. Chem. 2007, 282, 31317-31331. [CrossRef] [PubMed]

114. Wan, S.-G.; Taccioli, C.; Jiang, Y.; Chen, H.; Smalley, K.J.; Huang, K.; Liu, X.-P.; Farber, J.L.; Croce, C.M.; Fong, L.Y.Y. Zinc deficiency activates S100A8 inflammation in the absence of COX-2 and promotes murine oral-esophageal tumor progression. Int. J. Cancer 2011, 129, 331-345. [CrossRef] [PubMed]

115. Jin, Q.; Chen, H.; Luo, A.; Ding, F.; Liu, Z. S100A14 Stimulates Cell Proliferation and Induces Cell Apoptosis at Different Concentrations via Receptor for Advanced Glycation End Products (RAGE). PLoS ONE 2011, 6, e19375. [CrossRef]

116. Herwig, N.; Belter, B.; Pietzsch, J. Extracellular S100A4 affects endothelial cell integrity and stimulates transmigration of A375 melanoma cells. Biochem. Biophys. Res. Commun. 2016, 477, 963-969. [CrossRef]

117. Lin, J.; Blake, M.; Tang, C.; Zimmer, D.; Rustandi, R.R.; Weber, D.J.; Carrier, F. Inhibition of p53 Transcriptional Activity by the S100B Calcium-binding Protein. J. Biol. Chem. 2001, 276, 35037-35041. [CrossRef]

118. Lin, J.; Yang, Q.; Yan, Z.; Markowitz, J.; Wilder, P.T.; Carrier, F.; Weber, D.J. Inhibiting S100B Restores p53 Levels in Primary Malignant Melanoma Cancer Cells. J. Biol. Chem. 2004, 279, 34071-34077. [CrossRef]

119. Satyamoorthy, K.; Chehab, N.H.; Waterman, M.J.; Lien, M.C.; El-Deiry, W.S.; Herlyn, M.; Halazonetis, T.D. Aberrant regulation and function of wild-type p53 in radioresistant melanoma cells. Cell Growth Differ. 2000, 11, 467-474.

120. Yang, T.; Cheng, J.; Yang, Y.; Qi, W.; Zhao, Y.; Long, H.; Xie, R.; Zhu, B. S100B Mediates Stemness of Ovarian Cancer Stem-Like Cells Through Inhibiting p53. Stem Cells 2017, 35, 325-336. [CrossRef] 
121. Zhu, W.; Xue, Y.; Liang, C.; Zhang, R.; Zhang, Z.; Li, H.; Su, D.; Liang, X.; Zhang, Y.; Huang, Q.; et al. S100A16 promotes cell proliferation and metastasis via AKT and ERK cell signaling pathways in human prostate cancer. Tumor Biol. 2016, 37, 12241-12250. [CrossRef] [PubMed]

122. Chen, Q.Y.; Costa, M. PI3K/Akt/mTOR Signaling Pathway and the Biphasic Effect of Arsenic in Carcinogenesis. Mol. Pharmacol. 2018, 94, 784-792. [CrossRef] [PubMed]

123. Siveen, K.S.; Sikka, S.; Surana, R.; Dai, X.; Zhang, J.; Kumar, A.P.; Tan, B.K.H.; Sethi, G.; Bishayee, A. Targeting the STAT3 signaling pathway in cancer: Role of synthetic and natural inhibitors. Biochim. Biophys. Acta Rev. Cancer 2014, 1845, 136-154. [CrossRef] [PubMed]

124. Tan, B.; Shen, L.; Yang, K.; Huang, D.; Li, X.; Li, Y.; Zhao, L.; Chen, J.; Yi, Q.; Xu, H.; et al. C6 glioma-conditioned medium induces malignant transformation of mesenchymal stem cells: Possible role of S100B/RAGE pathway. Biochem. Biophys. Res. Commun. 2018, 495, 78-85. [CrossRef]

125. Zhang, F.; Banker, G.; Liu, X.; Suwanabol, P.A.; Lengfeld, J.; Yamanouchi, D.; Kent, K.C.; Liu, B.; Goldin, A.; Beckman, J.A.; et al. The novel function of advanced glycation end products in regulation of MMP-9 production. J. Surg. Res. 2011, 171, 871-876. [CrossRef]

126. Furtek, S.L.; Backos, D.S.; Matheson, C.J.; Reigan, P. Strategies and Approaches of Targeting STAT3 for Cancer Treatment. ACS Chem. Biol. 2016, 11, 308-318. [CrossRef] [PubMed]

127. Haase-Kohn, C.; Wolf, S.; Lenk, J.; Pietzsch, J. Copper-mediated cross-linking of S100A4, but not of S100A2, results in proinflammatory effects in melanoma cells. Biochem. Biophys. Res. Commun. 2011, 413, 494-498. [CrossRef]

128. Herwig, N.; Belter, B.; Wolf, S.; Haase-Kohn, C.; Pietzsch, J. Interaction of extracellular S100A4 with RAGE prompts prometastatic activation of A375 melanoma cells. J. Cell. Mol. Med. 2016, 20, 825-835. [CrossRef]

129. Tian, T.; Li, X.; Hua, Z.; Ma, J.; Wu, X.; Liu, Z.; Chen, H.; Cui, Z. S100A7 promotes the migration, invasion and metastasis of human cervical cancer cells through epithelial-mesenchymal transition. Oncotarget 2017, 8, 24964-24977. [CrossRef]

130. Taccioli, C.; Wan, S.-G.; Liu, C.-G.; Alder, H.; Volinia, S.; Farber, J.L.; Croce, C.M.; Fong, L.Y.Y. Zinc replenishment reverses overexpression of the proinflammatory mediator S100A8 and esophageal preneoplasia in the rat. Gastroenterology 2009, 136, 953-966. [CrossRef]

131. De Ponti, A.; Wiechert, L.; Schneller, D.; Pusterla, T.; Longerich, T.; Hogg, N.; Vogel, A.; Schirmacher, P.; Hess, J.; Angel, P. A pro-tumorigenic function of S100A8/A9 in carcinogen-induced hepatocellular carcinoma. Cancer Lett. 2015, 369, 396-404. [CrossRef] [PubMed]

132. Iotzova-Weiss, G.; Dziunycz, P.J.; Freiberger, S.N.; Läuchli, S.; Hafner, J.; Vogl, T.; French, L.E.; Hofbauer, G.F.L. S100A8/A9 stimulates keratinocyte proliferation in the development of squamous cell carcinoma of the skin via the receptor for advanced glycation-end products. PLoS ONE 2015, 10, e0120971. [CrossRef] [PubMed]

133. Wu, R.; Duan, L.; Cui, F.; Cao, J.; Xiang, Y.; Tang, Y.; Zhou, L. S100A9 promotes human hepatocellular carcinoma cell growth and invasion through RAGE-mediated ERK1/2 and p38 MAPK pathways. Exp. Cell Res. 2015, 334, 228-238. [CrossRef] [PubMed]

134. Huang, E.H.; Fuentes, M.K.; Arumugam, T.; Logsdon, C.D. The RAGE ligand, S100P, has increased expression in colon cancer. J. Am. Coll. Surg. 2004, 199, 18. [CrossRef]

135. Lin, J.; Yang, Q.; Wilder, P.T.; Carrier, F.; Weber, D.J. The Calcium-binding Protein S100B Down-regulates p53 and Apoptosis in Malignant Melanoma. J. Biol. Chem. 2010, 285, 27487-27498. [CrossRef]

136. Arumugam, T.; Ramachandran, V.; Logsdon, C.D. Effect of Cromolyn on S100P Interactions With RAGE and Pancreatic Cancer Growth and Invasion in Mouse Models. JNCI J. Natl. Cancer Inst. 2006, 98, 1806-1818. [CrossRef]

137. Onyeagucha, B.C.; Mercado-Pimentel, M.E.; Hutchison, J.; Flemington, E.K.; Nelson, M.A. S100P/RAGE signaling regulates microRNA-155 expression via AP-1 activation in colon cancer. Exp. Cell Res. 2013, 319, 2081-2090. [CrossRef]

138. Wu, T.S.; Tan, C.T.; Chang, C.C.; Lin, B.R.; Lai, W.T.; Chen, S.T.; Yen-Ping Kuo, M.; Rau, C.L.; Jaw, F.S.; Chang, H.H. B-cell lymphoma/leukemia 10 promotes oral cancer progression through STAT1/ATF4/S100P signaling pathway. Oncogene 2014, 34, 1207-1219. [CrossRef]

139. Mercado-Pimentel, M.E.; Onyeagucha, B.C.; Li, Q.; Pimentel, A.C.; Jandova, J.; Nelson, M.A. The S100P/RAGE signaling pathway regulates expression of microRNA-21 in colon cancer cells. FEBS Lett. 2015, 589, 2388-2393. [CrossRef] 
140. Hudson, B.I.; Lippman, M.E. Targeting RAGE Signaling in Inflammatory Disease. Annu. Rev. Med. 2018, 69, 349-364. [CrossRef]

141. Fallon, M.T. Neuropathic pain in cancer. Br. J. Anaesth. 2013, 111, 105-111. [CrossRef] [PubMed]

142. Esumi, S.; Kitamura, Y.; Yokota-Kumasaki, H.; Ushio, S.; Yamada-Takemoto, A.; Nagai, R.; Ogawa, A.; Kawasaki, Y.; Sendo, T. Effects of magnesium oxide on the serum duloxetine concentration and antidepressant-like effects of duloxetine in rats. Biol. Pharm. Bull. 2018, 41, 1727-1731. [CrossRef] [PubMed]

143. Matsuoka, H.; Makimura, C.; Koyama, A.; Otsuka, M.; Okamoto, W.; Fujisaka, Y.; Kaneda, H.; Tsurutani, J.; Nakagawa, K. Pilot study of duloxetine for cancer patients with neuropathic pain non-responsive to pregabalin. Anticancer Res. 2012, 32, 1805-1809. [PubMed]

144. Gao, H.; Zhang, I.Y.; Zhang, L.; Song, Y.; Liu, S.; Ren, H.; Liu, H.; Zhou, H.; Su, Y.; Yang, Y.; et al. S100B Suppression Alters Polarization of Infiltrating Myeloid-Derived Cells in Gliomas and Inhibits Tumor Growth. Cancer Lett. 2018, S0304-S3835, 30498-30501. [CrossRef]

145. Pellegrini, L.; Xue, J.; Larson, D.; Pastorino, S.; Jube, S.; Forest, K.H.; Saad-Jube, Z.S.; Napolitano, A.; Pagano, I.; Negi, V.S.; et al. HMGB1 targeting by ethyl pyruvate suppresses malignant phenotype of human mesothelioma. Oncotarget 2017, 8, 22649-22661. [CrossRef]

146. Chen, B.; Na, F.; Yang, H.; Li, R.; Li, M.; Sun, X.; Hu, B.; Huang, G.; Lan, J.; Xu, H.; et al. Ethyl pyruvate alleviates radiation-induced lung injury in mice. Biomed. Pharmacother. 2017, 92, 468-478. [CrossRef]

147. Liu, Q.; Huo, Y.; Zheng, H.; Zhao, J.; Jia, L.; Wang, P. Ethyl pyruvate suppresses the growth, invasion and migration and induces the apoptosis of non-small cell lung cancer cells via the HMGB1/RAGE axis and the NF-kB/STAT3 pathway. Oncol. Rep. 2019, 42, 817-825. [CrossRef]

148. Park, I.H.; Chung, S.K.; Lee, K.B.; Yoo, Y.C.; Kim, S.K.; Kim, G.S.; Song, K.S. An antioxidant hispidin from the mycelial cultures of Phellinus linteus. Arch. Pharm. Res. 2004, 27, 615-618. [CrossRef]

149. Lim, J.H.; Lee, Y.M.; Park, S.R.; Kim, D.H.; Lim, B.O. Anticancer Activity of Hispidin via Reactive Oxygen Species-mediated Apoptosis in Colon Cancer Cells. Anticancer Res. 2014, 34, 4087-4094.

150. Chandimali, N.; Huynh, D.L.; Jin, W.Y.; Kwon, T. Combination effects of hispidin and gemcitabine via inhibition of stemness in pancreatic cancer stem cells. Anticancer Res. 2018, 38, 3967-3975. [CrossRef]

151. Voigtlaender, M.; Langer, F. Low-Molecular-Weight Heparin in Cancer Patients: Overview and Indications. Hamostaseologie 2019, 39, 67-75. [CrossRef] [PubMed]

152. Mizumoto, S.; Takahashi, J.; Sugahara, K. Receptor for advanced glycation end products (RAGE) functions as receptor for specific sulfated glycosaminoglycans, and anti-RAGE antibody or sulfated glycosaminoglycans delivered in vivo inhibit pulmonary metastasis of tumor cells. J. Biol. Chem. 2012, 287, 18985-18994. [CrossRef] [PubMed]

153. Inada, M.; Shindo, M.; Kobayashi, K.; Sato, A.; Yamamoto, Y.; Akasaki, Y.; Ichimura, K.; Tanuma, S. Anticancer effects of a non-narcotic opium alkaloid medicine, papaverine, in human glioblastoma cells. PLoS ONE 2019, 14, e0216358. [CrossRef] [PubMed]

(C) 2020 by the authors. Licensee MDPI, Basel, Switzerland. This article is an open access article distributed under the terms and conditions of the Creative Commons Attribution (CC BY) license (http://creativecommons.org/licenses/by/4.0/). 